OPEN ACCESS

Edited by:

Sandra Macedo-Ribeiro,

Universidade do Porto, Portugal

Reviewed by:

Louise Charlotte Serpell,

University of Sussex, United Kingdom

Takashi Saito,

Nagoya City University, Japan

${ }^{*}$ Correspondence:

Eric W. Hewitt

e.w.hewitt@leeds.ac.uk

Received: 22 September 2020 Accepted: 03 November 2020

Published: 26 November 2020

Citation:

Brown MR, Radford SE and

Hewitt EW (2020) Modulation

of $\beta$-Amyloid Fibril Formation

in Alzheimer's Disease by Microglia

and Infection.

Front. Mol. Neurosci. 13:609073.

doi: 10.3389/fnmol.2020.609073

\section{Modulation of $\beta$-Amyloid Fibril Formation in Alzheimer's Disease by Microglia and Infection}

\author{
Madeleine R. Brown, Sheena E. Radford and Eric W. Hewitt* \\ School of Molecular and Cellular Biology and Astbury Centre for Structural Molecular Biology, Faculty of Biological Sciences, \\ University of Leeds, Leeds, United Kingdom
}

Amyloid plaques are a pathological hallmark of Alzheimer's disease. The major component of these plaques are highly ordered amyloid fibrils formed by amyloid- $\beta(A \beta)$ peptides. However, whilst $A \beta$ amyloid fibril assembly has been subjected to detailed and extensive analysis in vitro, these studies may not reproduce how $A \beta$ fibrils assemble in the brain. This is because the brain represents a highly complex and dynamic environment, and in Alzheimer's disease multiple cofactors may affect the assembly of $A \beta$ fibrils. Moreover, in vivo amyloid plaque formation will reflect the balance between the assembly of $A \beta$ fibrils and their degradation. This review explores the roles of microglia as cofactors in $A \beta$ aggregation and in the clearance of amyloid deposits. In addition, we discuss how infection may be an additional cofactor in $A \beta$ fibril assembly by virtue of the antimicrobial properties of $A \beta$ peptides. Crucially, by understanding the roles of microglia and infection in $A \beta$ amyloid fibril assembly it may be possible to identify new therapeutic targets for Alzheimer's disease.

Keywords: $\beta$-amyloid, $A \beta$, amyloid fibril, amyloid plaques, Alzheimer's disease, infection, microglia

\section{INTRODUCTION}

Alzheimer's disease (AD) is the most common form of dementia and is characterized by brain atrophy, amyloid plaques, intracellular neurofibrillary tangles, and neuroinflammation (Braak and Braak, 1991; Jack et al., 1998; Heppner et al., 2015). The amyloid plaques are primarily composed of fibrils formed by the $\beta$-amyloid ( $A \beta$ ) peptides (Wang et al., 1996). In AD A $\beta$ assembles into fibrils within the highly complex environment of the brain; as such multiple molecular and cellular factors may influence not only the formation the fibrils, but also their clearance. In contrast, $A \beta$ fibril formation is typically studied in vitro by incubating the purified peptide in simple solution conditions. This may not reproduce how $\mathrm{A} \beta$ fibrils assemble in the $\mathrm{AD}$ brain, and result in the generation of fibrils that have different properties to those formed in vivo. Indeed, $A \beta$ fibrils made in vitro do not efficiently induce amyloid plaque formation when injected into the hippocampus of young $\mathrm{AD}$ model mice, whereas brain extracts from $\mathrm{AD}$ patients and aged $\mathrm{AD}$ model mice lead to $A \beta$ deposition into plaques (Meyer-Luehmann et al., 2006). This suggests that there are cofactors present in vivo that promote $\mathrm{A} \beta$ fibril assembly and deposition in $\mathrm{AD}$. This review will focus on two potential cofactors, microglia and infection, and how these modulate $A \beta$ amyloid fibril assembly and whether these can be targeted to reduce plaque formation (Figure 1). 


\section{A $\beta$ AMYLOID FIBRIL ASSEMBLY}

$A \beta$ is formed by the sequential cleavage of transmembrane protein amyloid precursor protein (APP) by $\beta$-secretase and $\gamma$-secretase, resulting in $A \beta$ fragments ranging from 39 to 43 residues in length (Selkoe, 1998). The predominant forms of the peptide are the 40- and 42- residue peptide variants $A \beta_{1-40}$ and $A \beta_{1-42}$ (Wang et al., 1996). All known dominant mutations associated with early-onset AD occur in APP or in presenilin1 (PSEN1) and presenilin-2 (PSEN2), which are components of $\gamma$-secretase (Karch et al., 2014). Genome-wide association studies (GWAS) have also been used to identify genetic risk factors for late-onset $\mathrm{AD}$, and this has identified genes that encode proteins involved in APP processing including SORL1, ADAM10, and APH1B (Lambert et al., 2013; Jansen et al., 2019). This genetic evidence implicates $A \beta$ as an initiating factor in $\mathrm{AD}$.

$A \beta$ peptides are intrinsically disordered in their monomeric form and assemble into highly ordered fibrils via a nucleation dependent pathway, in which monomers self-associate to form a nucleus (Knowles et al., 2014). Addition of further $A \beta$ peptides to the nucleus culminates in the formation of fibrils, which can then be elongated by end on addition of $A \beta$ peptides. An array of oligomeric forms of $A \beta$ are associated with fibril assembly reactions and many studies point to a key role for these oligomers in neurotoxicity (Shankar et al., 2008; Evangelisti et al., 2016; Serra-Batiste et al., 2016). In addition, in secondary nucleation, the surface of existing $A \beta$ fibrils can catalyze the formation of new A $\beta$ fibrils (Cohen et al., 2013). Cross-seeding can also occur in which other protein complexes, including fibrils of other amyloidogenic sequences, provide surfaces for the secondary nucleation of $A \beta$ fibril assembly (Morales et al., 2013; Ono et al., 2014; Moreno-Gonzalez et al., 2017).

$\mathrm{A} \beta$ amyloid fibrils are highly ordered, with a common cross- $\beta$ structure, consisting of $\beta$-sheets in which in-register $\beta$-strands are oriented perpendicularly to the fibril axis, with 4.6-4.7 ̊ spacing between them (Eanes and Glenner, 1968). Fibrils are unbranched, typically $5-15 \mathrm{~nm}$ in width, can reach up to several microns in length and can consist of a number of cross $-\beta$ subunits (Iadanza et al., 2018). These subunits are protofilaments which associate to form a mature $A \beta$ fibril (Iadanza et al., 2018). While all $A \beta$ fibrils share this characteristic cross $-\beta$ structure, polymorphism refers to the different molecular structure of the peptide within this cross- $\beta$ subunit, and also the different number and arrangement of the cross- $\beta$ subunits that make up a mature fibril (Tycko, 2015). While A $\beta$ fibrils formed both in vitro and derived from ex vivo patient tissue exhibit polymorphism, the structures determined to date of fibrils derived from $\mathrm{AD}$ patient tissue are distinct from those formed in vitro (Petkova et al., 2005; Paravastu et al., 2008, 2009; Lu et al., 2013; Qiang et al., 2017; Kollmer et al., 2019). In addition, it was shown that synthetic $A \beta$ fibrils do not efficiently induce $A \beta$-plaque formation when injected into the hippocampus of young $\mathrm{AD}$ model (APP23) mice, whereas brain extracts from AD patients and aged APP23 mice led to A $\beta$ deposition (Meyer-Luehmann et al., 2006). This suggests that a cofactor, or multiple cofactors within the brain, could be required to drive $A \beta$ assembly and deposition in vivo (Meyer-Luehmann et al., 2006).

\section{MICROGLIA AND THE IMMUNE RESPONSE TO A $\beta$ AMYLOID FIBRILS}

Microglia are immune cells that are resident in the brain, and depending on the region, make up $0.5-16 \%$ of all cells in the human brain (Mittelbronn et al., 2001; Ajami et al., 2007; Ginhoux et al., 2010). When in a resting state, microglia have a ramified morphology, multiple fine processes project from the cell body, which are used to monitor the central nervous system (CNS) microenvironment (Nimmerjahn et al., 2005). These cells respond to changes in the local environment and migrate to activating stimuli, adopting a more amoeboid morphology and expressing an altered repertoire of receptors (Davalos et al., 2005). Reactive microglia are observed in AD brains, in close association with $\mathrm{A} \beta$ plaques (Itagaki et al., 1989; Yuan et al., 2016). A $\beta$ fibrils have been shown to activate the production of pro-inflammatory cytokines by microglia and thus may be a stimulus for the increased production of these cytokines, which contribute to the neurodegeneration associated with AD (Griffin et al., 1989; Bauer et al., 1991; Patel et al., 2005; Halle et al., 2008; Ojala et al., 2009). However, in addition to cytokine production, microglia may also modulate the formation of $\mathrm{A} \beta$ amyloid fibrils and plaques. Crucially, microglia can affect both the generation and the degradation of $A \beta$ fibrils. The balance between these activities may therefore represent a key determinant in whether amyloid plaques accumulate in the $\mathrm{AD}$ brain.

\section{FORMATION OF PHYSICAL BARRIERS AROUND A $\beta$ AMYLOID PLAQUES BY MICROGLIA}

In $\mathrm{AD}$ microglia migrate to, surround and infiltrate $\mathrm{A} \beta$ amyloid plaques, where they come into close contact with $A \beta$ fibrils (Itagaki et al., 1989). In AD mice models this recruitment can occur as quickly as within a day of plaque formation and results in a two-fivefold increase in microglia at $A \beta$ plaques compared to the neighboring tissue (Frautschy et al., 1998; Simard et al., 2006; Meyer-Luehmann et al., 2008). Microglia have been shown to surround plaques forming a barrier that limits their outward growth by preventing the recruitment of $A \beta$ peptides (Condello et al., 2015). Plaques with less microglial coverage were less compact and had increased recruitment of soluble $A \beta_{1-42}$, allowing the formation of $A \beta_{1-42}$ protofibrils (Condello et al., 2015). Similar results were found after depletion of microglia with PLX5622, an inhibitor of the essential microglial colony stimulating factor 1 receptor (CSF1R) signaling pathway (Spangenberg et al., 2019). These hotspots of $A \beta_{1-42}$ protofibrils were found to be neurotoxic, resulting in more severe neuritic dystrophy (Condello et al., 2015). This supports the role of microglia in the formation of a physical barrier around fibrillar plaques, compacting 


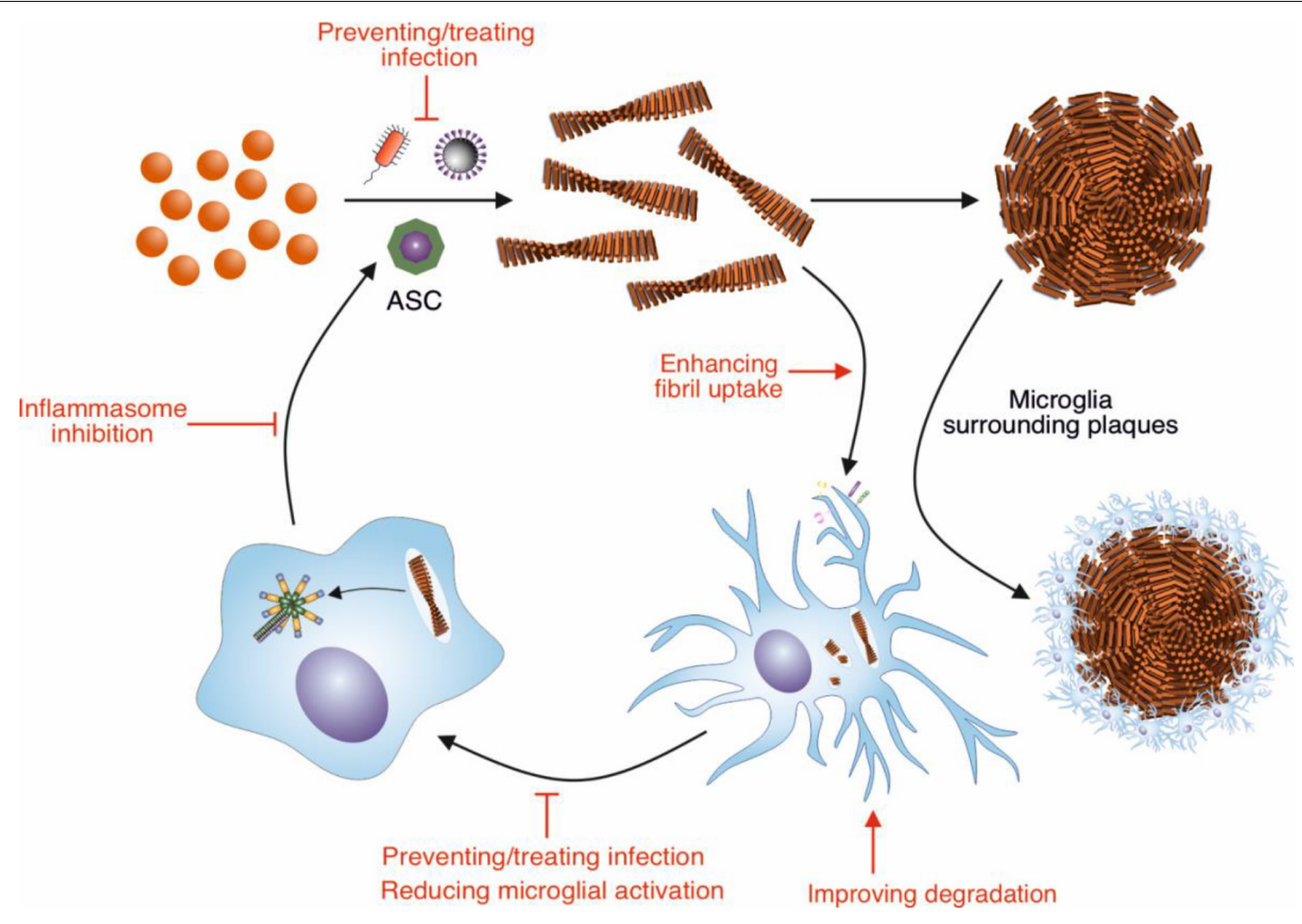

FIGURE 1 | Modulation of $A \beta$ amyloid fibril assembly and clearance by microglial cells and infection, and potential targets of intervention. A $\beta$ peptide assembles into highly ordered amyloid fibrils with a characteristic cross- $\beta$ structure. These fibrils form the core of amyloid plaques present in AD brains. Microglia surround these plaques, forming a protective barrier around them, limiting the recruitment of further A $\beta$. Microglia can also contribute to the clearance of $A \beta$ fibrils. In order to remove $A \beta$ deposits in $A D$, the phagocytic activity of microglia could be enhanced by targeting receptors and pathways involved in this response, such as TREM2 and CD33. Increasing the breakdown by microglial proteases could also enhance clearance of A $\beta$ deposits. The NLRP3 inflammasome in microglia is concurrently activated in response to $A \beta$ fibrils, resulting in the release of ASC specks. These specks cross-seed the formation of $A \beta$ fibrils, resulting in further $A \beta$ aggregation. Therefore, inhibiting the activation of the NLRP3 inflammasome would reduce the cross seeding of A $\beta$ aggregation by ASC specks. A $\beta$ also has antimicrobial and antiviral-properties, assembling into amyloid fibrils in response to infection. Thus, infection could be targeted to reduce $A \beta$ aggregation.

plaque cores, limiting growth and reducing neurite dystrophy (Condello et al., 2015).

An array of genes is associated with the development of late-onset AD (Karch et al., 2014; Jansen et al., 2019). One of these genes encodes triggering receptor expressed on myeloid cells 2 (TREM2), an immune receptor of the immunoglobulin family, which is expressed by microglia (Lambert et al., 2013). TREM2 sequence variants $\mathrm{R} 47 \mathrm{H}$ and $\mathrm{R} 62 \mathrm{H}$ have been found to increase the risk of developing late-onset $\mathrm{AD}$ (Jonsson et al., 2013; Chih Jin et al., 2014). This plasma membrane receptor forms signaling complexes with the adaptor protein DNAX-activating protein of $12 \mathrm{kDa}$ (DAP12), and is important in the phagocytosis of apoptotic neurons and the negative regulation of inflammatory responses (Hamerman et al., 2005, 2006; Takahashi et al., 2005; Piccio et al., 2007; Hsieh et al., 2009). In AD model mice, the deletion of TREM 2 did not significantly affect $A \beta$ deposition, but it did reduce the extent to which microglia surrounded $A \beta$ plaques (Ulrich et al., 2014; Wang et al., 2016). Plaques were more diffuse, and this was associated with an increased level of neuritic damage. This suggests a requirement for TREM2 in the formation of a neuroprotective microglial barrier. In support of this role for
TREM2, Yuan et al. (2016) found that mice haplodeficient for TREM2 or DAP12 and humans harboring the R47H TREM2 mutation had a reduced microglial barrier surrounding $A \beta$ plaques, and reduced plaque compaction. The $A \beta$ fibrils in these plaques were found to be longer and there was more evidence of $A \beta$ nanostructures extending out from the main $\mathrm{A} \beta$ fibril bundle, allowing more interaction with nearby neurites (Yuan et al., 2016).

\section{CLEARANCE OF A $\beta$ BY MICROGLIA}

In addition to surrounding amyloid plaques, the microglia recruited to these plaques may be involved in clearing these amyloid deposits (Rogers et al., 2002). Microglia are thought to contribute to the clearance of $A \beta$ via the secretion of amyloid-degrading enzymes and by the internalization of $\mathrm{A} \beta$ fibrils. Furthermore, analysis of gene regulatory networks in late-onset $\mathrm{AD}$ identified that immune and microglial molecular networks were most associated with late-onset $\mathrm{AD}$ (Zhang et al., 2013). A number of these risk genes have been found to be involved in the clearance of $\mathrm{A} \beta$ (Kleinberger et al., 
2014; Ulrich et al., 2018; Griciuc et al., 2019) highlighting the importance of this process in $\mathrm{AD}$.

\section{Secreted Microglial Proteases}

Enzymes that cleave $A \beta$ include the metalloendopeptidases insulin-degrading enzyme (IDE) and neprilysin (NEP). Microglia are thought to contribute to the secretion of these enzymes, along with neurons and astrocytes, and a decrease in microglial expression of both enzymes is associated with aging in $\mathrm{AD}$ model mice (Leissring et al., 2003; Hickman et al., 2008; Tamboli et al., 2010). These enzymes, however, are thought to be limited to the degradation of monomeric peptide, and do not contribute to the degradation of $\mathrm{A} \beta$ amyloid fibrils (Qiu et al., 1998; Farris et al., 2003; Leissring et al., 2003). There is also evidence on the capability of NEP to degrade some oligomeric forms of $\mathrm{A} \beta$. The enzyme was found to degrade oligomers formed from synthetic $A \beta$ peptide, but in another study NEP did not degrade $\mathrm{A} \beta$ oligomers secreted from cells overexpressing APP (Kanemitsu et al., 2003; Leissring et al., 2003).

Secreted enzymes capable of cleaving fibrillar A $\beta$ have, however, been identified. Metalloprotease-9 (MMP-9) is a zincdependent metalloprotease expressed by neurons, astrocytes, microglia and vascular cells in the brain (Vafadari et al., 2016). It was shown that incubation of $A \beta_{1-40}$ and $A \beta_{1-42}$ fibrils with MMP-9 leads to their degradation (Yan et al., 2006). Fibril fragments produced were analyzed using mass spectrometry and this revealed species corresponding to $A \beta_{1-20}$ and $A \beta_{1-30}$, suggesting Phe20-Ala21 and Ala30-Ile31 as cleavage sites (Yan et al., 2006). These sites must be accessible to MMP-9 in the fibril structure. MMP-9 was also found to degrade compact $A \beta$ amyloid plaques in brain sections from AD model (APP/PS1) mice (Yan et al., 2006). MMP-2 is implicated in the degradation of soluble $A \beta$, with increased $A \beta_{1-40}$ and $A \beta_{1-42}$ identified in the soluble fraction of cortex and hippocampal brain samples of knock out MMP-2 mice compared to wild-type controls (Yin et al., 2006).

\section{Uptake and Degradation of A $\beta$ Fibrils by Microglia}

Consistent with a role in the clearance of $A \beta$, microglia express an array of receptors that facilitate the uptake of $A \beta$ aggregates.

\section{Toll-Like Receptors}

One family of receptors involved in the immune response to $A \beta$ amyloid are the Toll-like receptors (TLRs) a class of pattern recognition receptors that recognize conserved microbial structures (Kawasaki and Kawai, 2014). TLRs are type I integral membrane proteins which recognize ligands with their leucinerich repeat (LRR)-containing ectodomains. RNA sequencing revealed that the expression of six TLR genes $(1,2,4,5,6,8)$ is upregulated in the temporal cortex of $\mathrm{AD}$ patients when compared to control brains, likely resulting from increased microglial activation (Chakrabarty et al., 2018). A direct interaction was identified between A $\beta$ fibrils and CD14, a TLR coreceptor previously shown to associated with the inflammatory response to fibrillar A $\beta$ (Fassbender et al., 2004; Reed-Geaghan et al., 2009). This interaction was shown to facilitate the internalization of $\mathrm{A} \beta$ fibrils by microglia, at lower concentrations than that required for cell activation (Liu et al., 2005). This suggests that CD14 could be involved in the phagocytosis of $\mathrm{A} \beta$ fibrils at low concentrations, but increased $\mathrm{A} \beta$ levels in $\mathrm{AD}$ results in cellular activation. Consistent with a role in $A \beta$ uptake, TLR4 deficiency in AD mouse models results in increased fibrillar and soluble A $\beta$ deposition (Tahara et al., 2006). Conversely, stimulation of the murine microglial cell line BV-2 with TLR2 and TLR4 ligands significantly increased the internalization of $\mathrm{A} \beta$ in vitro, further implicating TLR receptors in $A \beta$ uptake and clearance (Tahara et al., 2006; Song et al., 2011).

\section{Scavenger Receptors}

Another family of receptors found to be involved in the internalization of $\mathrm{A} \beta$ fibrils are the scavenger receptors (SRs), which are highly expressed by microglia (Christie et al., 1996; Wilkinson and El Khoury, 2012). It was found initially that class A SRs, characterized by an extracellular collagen-like domain, are involved in the binding to A $\beta$ fibrils to microglial cells (El Khoury et al., 1996). It was then shown that coincubation of microglia with SR ligands such as acetyl-low density lipoprotein (Ac-LDL) reduced $\mathrm{A} \beta$ uptake, and $\mathrm{CHO}$ cells transfected with class $\mathrm{A}$, or class B SR's showed enhanced A $\beta$ uptake, suggesting that SRs are important in the uptake and clearance of $A \beta$ (Paresce et al., 1996). Further investigation using microglia that are deficient in SR-A1 confirmed the role of SR-A1 and also SR-B1 in binding $A \beta$ fibrils, consistent with a role in the clearance of $A \beta$ amyloid (Husemann et al., 2001). CD36 is a class B scavenger receptor identified to form a receptor complex with the $\alpha_{6} \beta_{1}$-integrin and the integrin-associated protein CD47 in microglia. This complex was shown to mediate the binding of $\mathrm{A} \beta$ fibrils to microglial cells and the subsequent activation of intracellular signaling pathways (Bamberger et al., 2003). While initial studies reported that $A \beta$ fibril binding to this complex is largely involved in the activation of an inflammatory response, it was also reported that the interaction of $A \beta$ fibrils with this complex is involved in the phagocytic uptake of fibrils by microglia (Coraci et al., 2002; Moore et al., 2002; Bamberger et al., 2003; Koenigsknecht and Landreth, 2004).

\section{TREM2}

The deletion of TREM2 in primary microglia was shown to significantly reduce the phagocytosis of aggregated $A \beta_{1-42}$ (Kleinberger et al., 2014). Similarly, TREM2 deficiency reduced the efficacy of antibody-targeted $\mathrm{A} \beta$ phagocytosis by microglia (Xiang et al., 2016). There is evidence for direct interactions between TREM2 and $A \beta_{1-42}$ fibrils, although no difference in binding affinity was identified for TREM2 R47H and $\mathrm{R} 62 \mathrm{H}$ variants that are associated with an increased risk of AD (Lessard et al., 2018). However, the internalization of monomeric $A \beta$ was reduced with the expression of these TREM2 AD variants (Lessard et al., 2018). In another study, TREM2 was found to bind to $A \beta$ oligomers with a similar affinity to previously described $\mathrm{A} \beta$ receptors, CD36 and receptor for advanced glycation end products (RAGE), and this interaction was compromised by $\mathrm{R} 47 \mathrm{H}$ and R62H TREM2 mutations (Zhao et al., 2018). In this study, TREM 2 deficiency had little effect on A $\beta$ uptake but led to significantly reduced $A \beta$ degradation once internalized by 
microglia (Zhao et al., 2018). In TREM2 knock out mice injected with $A \beta$ oligomers, there was reduced microglial migration to the site of injection and reduced $\mathrm{A} \beta$ clearance (Zhao et al., 2018). A recent study found that loss of TREM2 function led to an acceleration in early amyloidogenesis, accompanied by a reduction in microglial recruitment as previously described, again suggesting that TREM2 has a role in microglial clearance of $\mathrm{A} \beta$ (Parhizkar et al., 2019). Together this evidence suggests that $\mathrm{A} \beta$ is a ligand for TREM2, and that TREM2 has a role to play in both $\mathrm{A} \beta$ clearance and $\mathrm{A} \beta$-stimulated microglial activation.

\section{A Novel Role for the Autophagy Machinery in A $\beta$ Receptor Recycling}

$\mathrm{A} \beta$ clearance by microglia may involve proteins of the autophagy machinery in a pathway distinct from their canonical function (Heckmann et al., 2019). This pathway is referred to as LC3associated endocytosis (LANDO), with LC3 being a key protein in macroautophagy. Evidence from this study suggests that LANDO facilitates recycling of the $A \beta$ receptors CD36, TLR4 and TREM 2 , thus allowing cycles of $A \beta$ endocytosis to continue, promoting $A \beta$ uptake and clearance (Heckmann et al., 2019). The autophagy proteins ATG5 and Rubicon were found to be protective against $A \beta$ deposition, with their absence leading to increased pathology. The expression of autophagy proteins declines with age, which may be related to the development of $\mathrm{A} \beta$ pathology in $\mathrm{AD}$ (Rubinsztein et al., 2011). It is important to note that macroautophagy has previously been implicated in the secretion of $A \beta$ into the extracellular space where it forms plaques in AD (Nilsson et al., 2013). When autophagyrelated gene 7 (ATG7) was conditionally knocked out in excitatory neurons of APP transgenic mice, extracellular A $\beta$ plaque pathology was significantly decreased, and $A \beta$ instead accumulated intracellularly (Nilsson et al., 2013). Thus, a reduction in expression of proteins involved in macroautophagy could affect both $A \beta$ secretion and clearance.

\section{CD33}

CD33, a type 1 transmembrane protein, is a sialic acid-binding immunoglobulin-like lectin (Siglec) expressed by immune cells, and was identified by GWAS to be associated with AD (Hollingworth et al., 2011). In addition, CD33-positive microglia and CD33 protein levels were found to be increased in $\mathrm{AD}$ brains, and CD33 was found to be associated with cognitive decline (Karch et al., 2012; Griciuc et al., 2013). It was found that a rs3865444 allele that was found to be protective in AD led to a reduction in the level of insoluble $A \beta$ in the $A D$ brain, suggesting a role for $\mathrm{CD} 33$ in mediating the clearance of $\mathrm{A} \beta$ (Griciuc et al., 2013). Furthermore, a risk allele of rs3865444 was associated with reduced $\mathrm{A} \beta_{1-42}$ internalization, and an increase in fibrillar amyloid, and neuritic amyloid pathology in $\mathrm{AD}$ patients, supporting the involvement of CD33 in the modulation of $A \beta$ clearance (Bradshaw et al., 2013). Recent work by Griciuc et al. (2019) showed that knockout of CD33 led to mitigated $\mathrm{A} \beta$ pathology in $5 x \mathrm{xAD} \mathrm{AD}$ model mice, with genes related to phagocytosis found to be upregulated (Griciuc et al., 2019). The opposite effects were found to result from TREM2 knockout (Griciuc et al., 2019). Interestingly, this differential gene expression in CD33 deficient 5xFAD mice only occurred in the presence of TREM2, suggesting that TREM2 acts downstream of CD33 (Griciuc et al., 2019).

\section{Degradation of $A \beta$ Fibrils by Lysosomal Proteases}

Once internalized A $\beta$ fibrils are sorted to lysosomes, a degradative organelle which contains proteases that are capable of degrading $\mathrm{A} \beta$ fibrils (Paresce et al., 1997). A $\beta_{1-42}$ monomeric peptide, non-fibrillar assemblies and fibrils were all shown to be cleaved by the lysosomal cysteine protease cathepsin $\mathrm{B}$, resulting in the production of $A \beta_{1-40}, A \beta_{1-38}$ and $A \beta_{1-33}$ in a dose-dependent manner (Mueller-Steiner et al., 2006). This suggests an antiamyloidogenic role for cathepsin $\mathrm{B}$, via the $\mathrm{C}$-terminal truncation of $A \beta$. In addition to this, cathepsin $B$ was found to accumulate in mature amyloid plaques in AD model mice. Cathepsin B activity was highest in supernatant taken from primary microglial cell cultures, compared to neurons and astrocytes, suggesting that these cells act as a source of cathepsin B as they surround $A \beta$ plaques (Mueller-Steiner et al., 2006). The lysosomal protease, tripeptidyl peptidase 1 (TPP1) is another enzyme capable of cleaving $A \beta$ fibrils. Digestion of $A \beta_{1-42}$ fibrils in vitro by TPP1 revealed a number of different cleavage sites within the $\beta$-sheet domains, and molecular dynamics simulations demonstrated that these cleavages lead to destabilization of the $\beta$-sheet fibril structure (Solé-Domènech et al., 2018).

\section{Failure of Microglia to Clear $\mathbf{A} \beta$ Amyloid Fibrils in AD}

Although evidence suggests that $\mathrm{A} \beta$ amyloid fibrils can be internalized by microglia and degraded by lysosomal and secreted proteases, microglia may be limited in their capacity to clear $\mathrm{A} \beta$. This is evidenced by the accumulation of amyloid plaques in the $\mathrm{AD}$ brain despite microglial recruitment. A number of studies support this notion (Paresce et al., 1997; Majumdar et al., 2008). Fluorescently labeled $A \beta$ fibrils internalized by cultured microglia were trafficked to lysosomes, however, $A \beta$ was not degraded and was retained in microglial cells over a 3-day chase period (Majumdar et al., 2008). This was due to the inefficient delivery of chloride transporter CIC-9 to lysosomes, resulting in incomplete lysosome acidification and reduced activity of lysosomal proteases in the microglial (Majumdar et al., 2011).

Similarly, the genetic risk factor for $\mathrm{AD}$, the $\varepsilon 4$ allele of $\mathrm{ApoE}$, may impair the ability of microglia to remove $A \beta$ deposits. ApoE is a key cholesterol carrier, primarily produced by astrocytes in the brain, but also to some extent by microglia, and facilitates the transport of lipids via receptors of the low-density lipoprotein receptor (LDLR) family (Bu, 2009). Three common isoforms of ApoE exist in humans; $\varepsilon 2 \varepsilon 3$ and $\varepsilon 4$ (Mahley, 1988). The $\varepsilon 4$ allele of ApoE is the strongest genetic risk factor for late-onset $\mathrm{AD}$, whereas the $\varepsilon 2$ allele has a protective effect (Lambert et al., 2013). ApoE deletion in AD mouse models leads to reduced $\mathrm{A} \beta$ plaque deposition, implicating ApoE in $\mathrm{A} \beta$ amyloidogenesis and/or clearance (Bales et al., 1997; Ulrich et al., 2018). The efficiency of soluble $A \beta$ clearance from the interstitial fluid of the 
brain is dependent on the ApoE isoform, with ApoE4 resulting in the least efficient clearance (Castellano et al., 2011). A number of mechanisms by which ApoE influences $A \beta$ clearance have been proposed. In microglia, it was reported that lipidated forms of ApoE stimulate the degradation of soluble $A \beta$ by NEP, with ApoE4 being the least efficient at promoting this degradation, and ApoE2 having the strongest effect (Jiang et al., 2008). There is also evidence to suggest that ApoE results in faster delivery of $A \beta$ to lysosomes in microglia, by lowering cellular cholesterol levels, and the efficiency of this cholesterol efflux activity is isoform-dependent (Hara et al., 2003; Lee et al., 2011). Furthermore, microglial-like cells derived from human induced pluripotent stem cells expressing ApoE4 displayed reduced oligomeric $A \beta_{1-42}$ phagocytosis compared to ApoE3 cells (Lin et al., 2018).

The ability of microglia to clear amyloid deposits in $\mathrm{AD}$ may also be diminished as a consequence of aging. Indeed, when production and clearance rates of $A \beta_{1-40}$ and $A \beta_{1-42}$ were tracked in $\mathrm{AD}$ patients using metabolic labeling, it was found that clearance rates for both peptides were reduced in $\mathrm{AD}$ compared to controls, but there were no differences in the rates of their production (Mawuenyega et al., 2010). This may be due to a reduced capacity of microglia to internalize $A \beta$ fibrils. Microglia from older AD model mice have a twofold to sixfold reduction in expression of $A \beta$-binding receptors SR-A, CD36 and RAGE compared to wild type controls, in addition there was a significant reduction in the expression of secreted $A \beta$-degrading enzymes IDE, NEP and MMP-9 (Hickman et al., 2008). Old $\mathrm{AD}$ model mice were also found to have increased expression of inflammatory cytokines tumor necrosis factor- $\alpha$ (TNF- $\alpha$ ) and interleukin-1 $\beta$ (IL-1 $\beta$ ), indicating that while clearance pathways are impaired, a damaging inflammatory response to $A \beta$ could be exacerbated (Hickman et al., 2008). A later study also found an impairment in phagocytic activity in $\mathrm{AD}$ mice compared to wild type controls, and this impairment correlated with an increased deposition of A $\beta$ (Krabbe et al., 2013). Reducing A $\beta$ load by administering an anti-A $\beta$ antibody restored the phagocytic capacity of microglia, suggesting that the microglial dysfunction is a result of AD pathology (Krabbe et al., 2013).

A number of subset populations of microglia have been identified in aging and AD brains, with distinct transcriptional profiles and phenotypes (Keren-Shaul et al., 2017; Krasemann et al., 2017; Marschallinger et al., 2020). These include 'damage associated microglia' (DAM) which are proposed to play a protective role in disease (Keren-Shaul et al., 2017), and microglia with a neurodegenerative phenotype, which have lost their homeostatic function (Krasemann et al., 2017). The switch of microglia to this impaired neurodegenerative phenotype was found to be dependent on APOE signaling induced by TREM2, further implicating these pathways and microglial dysfunction in AD (Krasemann et al., 2017). Furthermore, a unique population was recently identified in the aging brain, termed 'lipid-dropletaccumulating microglia' (LDAM), which show a build-up of lipid droplets, and possess a distinct transcriptional signature (Marschallinger et al., 2020). Importantly, these microglia show defects in phagocytosis, as well as increased release of proinflammatory cytokines (Marschallinger et al., 2020). LDAM accounted for up to $50 \%$ of microglia in the hippocampus of aged mice, but have yet to be confirmed in AD models or brains (Marschallinger et al., 2020). Frigerio et al. (2019) showed that a microglial population termed 'activated response microglia' (ARMs) occur naturally in aging mice and in human brain, but the conversion to this state is accelerated in response to $A \beta$ plaques (Frigerio et al., 2019). A number of AD risk genes including ApoE were found to be upregulated in ARMs, conversely depletion of ApoE blocked the recruitment of microglia to $A \beta$ plaques (Frigerio et al., 2019). Given the association of the ApoE4 allele with $\mathrm{AD}$, future studies should investigate whether this allele influences the production of ARMs (Lambert et al., 2013). Nonetheless, the implication of these data is that both aging and $\mathrm{AD}$ affect the phenotypes of microglia and thus their responses to $A \beta$.

\section{CLEARANCE OF A $\beta$ BY ASTROCYTES}

In addition to microglia, astrocytes may play a role in the clearance of $\mathrm{A} \beta$. Astrocytes, the most abundant glial cell in the brain, have numerous crucial roles in maintaining and regulating neuronal function and signal transmission (Perez-Nievas and Serrano-Pozo, 2018). Like microglia, astrocytes can react to pathogenesis by adopting a reactive phenotype, and this reactive astrogliosis is observed in $\mathrm{AD}$ brains, with a close relationship to A $\beta$ pathology (Itagaki et al., 1989; Nagele et al., 2003; PerezNievas and Serrano-Pozo, 2018). Moreover, astrocytes may also contribute to the clearance of $\mathrm{A} \beta$ fibrils in $\mathrm{AD}$ and as discussed above the secreted protease MMP-9 is produced by a number of cell types including astrocytes (Vafadari et al., 2016). Astrocytes also secrete the MMP membrane type-1 (MT1) and kallikreinrelated peptidase 7 (KLK7) (Liao and Van Nostrand, 2010; Kidana et al., 2018). MT1 is expressed by reactive astrocytes close to $\mathrm{A} \beta$ deposits and was shown to degrade $\mathrm{A} \beta$ plaques in an $\mathrm{AD}$ (APP) mouse model and cleave $A \beta_{1-42}$ fibrils in vitro (Liao and Van Nostrand, 2010). KLK7 was found to cleave $A \beta$ in the hydrophobic core motif of fibrils (KLVFFA), thus preventing fibril formation and promoting the degradation of pre-formed fibrils (Shropshire et al., 2014). KLK7 shows A $\beta$-degrading activity in vitro, and deletion of KLK7 in $\mathrm{AD}$ mice resulted in increased fibrillar A $\beta$ pathology (Kidana et al., 2018). Further to this, KLK7 mRNA levels were found to be reduced in AD brains (Kidana et al., 2018).

A number of studies have also reported the ability of astrocytes to internalize $A \beta$, resulting in the accumulation of $A \beta_{1-42}$ within activated astrocytes (Nagele et al., 2003; Wyss-Coray et al., 2003; Nielsen et al., 2010; Pihlaja et al., 2011). Cultured astrocytes were shown to migrate toward C-C motif ligand 2 (CCL2), a chemokine present at $\mathrm{AD}$ plaques, and subsequently bind to $A \beta$, although the receptors involved in in $A \beta$ binding were not identified (Wyss-Coray et al., 2003). ApoE deficient astrocytes are, however, less efficient in the internalization and degradation of $\mathrm{A} \beta$ deposits compared to wild-type cells, thus implicating ApoE in astrocytic A $\beta$ clearance (Koistinaho et al., 2004). Moreover, in a study of $\mathrm{AD}$ brain tissue, $\mathrm{A} \beta$ present within astrocytes was suggested to result from the phagocytosis of debris 


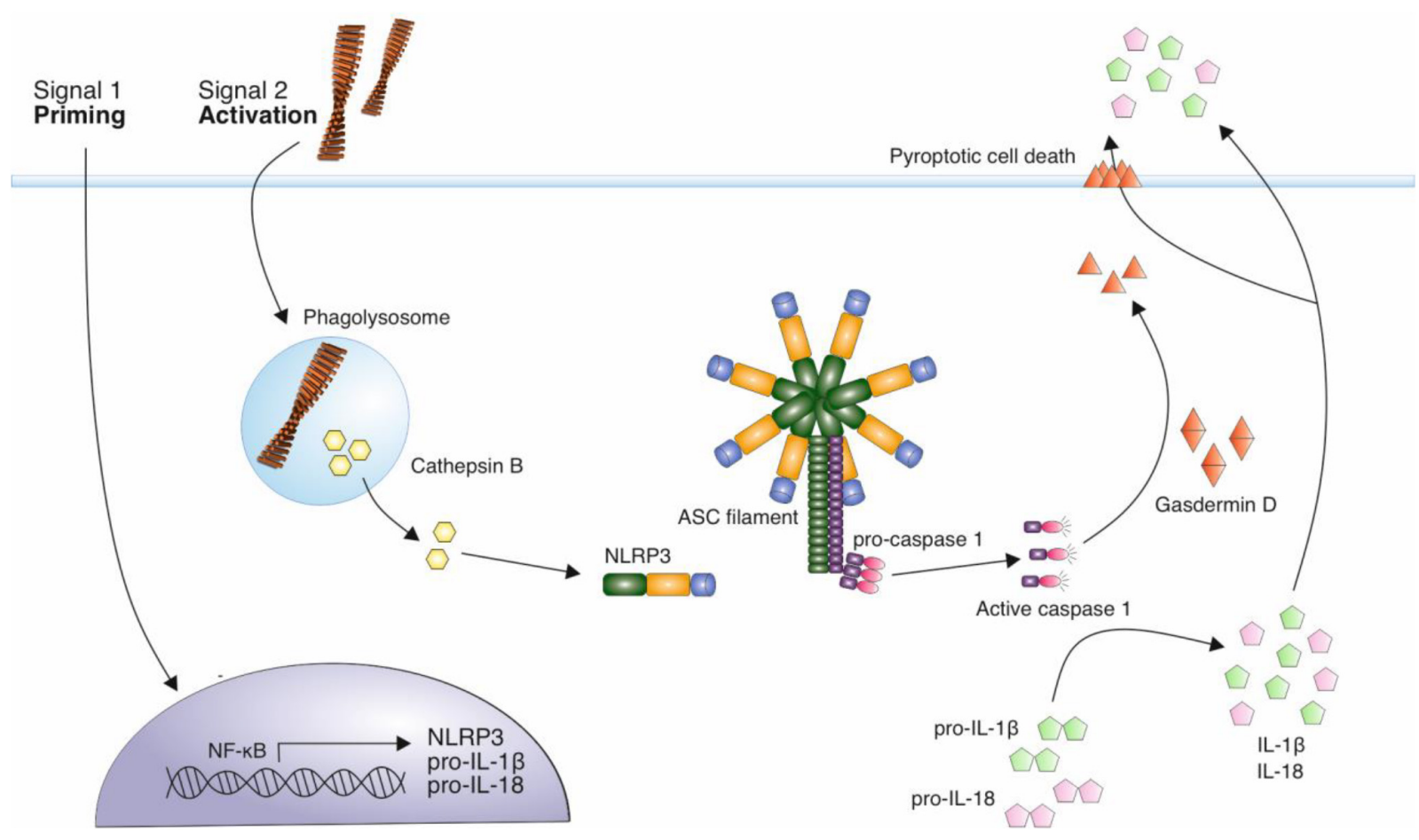

FIGURE 2 | Mechanism of NLRP3 activation by amyloid fibrils. A priming signal, such as LPS, leads to the increased expression of NLRP3 and precursor forms of inflammatory cytokines IL-1 $\beta$ and IL-18. A $\beta$ fibrils act as an activating stimulus via their internalization and disruption of lysosomes leading to the release of cathepsin $\mathrm{B}$ into the cytosol. This is thought to trigger the assembly of the NLRP3 inflammasome complex. This complex recruits ASC adaptor protein, which forms filaments. ASC filaments interact with pro-caspase 1 via CARD domains, resulting in caspase-1 activation. Active caspase 1 cleaves precursor forms of IL-1 $\beta$ and IL-18, which are secreted from immune cells in their active form, contributing to neuroinflammation. Caspase 1 also cleaves gasdermin $\mathrm{D}$, which forms pores in the cell membrane, eventually resulting in pyroptotic cell death.

derived from damaged neurons, as neuron-specific markers were also identified (Nagele et al., 2003).

\section{INFLAMMASOMES AND THE CROSS SEEDING OF A $\beta$ AGGREGATION}

A role for activated microglia in the production of proinflammatory cytokines is well documented, and $A \beta$ fibrils can act as a stimulus for this activation (Halle et al., 2008; Reed-Geaghan et al., 2009; Stewart et al., 2010). However, the pathway for the production of pro-inflammatory cytokines IL-1 $\beta$ and interleukin-18 (IL-18) in microglia may also promote $A \beta$ fibril formation (Venegas et al., 2017). Thus, the relationship between microglia and $A \beta$ is complex, and instead of attempting to remove amyloid plaques, microglia may also be playing a role in the formation of $A \beta$ amyloid fibrils.

The NOD-like receptor family, pyrin domain containing 3 (NLRP3) inflammasome, is involved in the production and release of the pro-inflammatory cytokines IL-1 $\beta$ and IL-18 (Swanson et al., 2019). The activation of the inflammasome is a two-step process, requiring a priming stimulus followed by an activating stimulus. The priming stimulus can be cytokines, such as TNF- $\alpha$ and IL-1 $\beta$, or pathogen associated molecular patterns (PAMPs) such as bacterial lipopolysaccharide
(LPS) (Bauernfeind et al., 2009; Franchi et al., 2009). This priming step results in the transcriptional upregulation of inflammasome components, NALP3 and inactive forms of IL$1 \beta$, IL-18 and caspase-1 (Bauernfeind et al., 2009; Franchi et al., 2009). A number of stimuli can act as a second activating stimulus, including ATP, pore-forming toxins that result in low intracellular $\mathrm{K}^{+}$, crystalline structures such as uric acid and silica, and A $\beta$ fibrils (Mariathasan et al., 2006; Martinon et al., 2006; Halle et al., 2008). The activating stimulus leads to the oligomerization of NLRP3, and the recruitment of adaptor protein apoptosis-associated specklike protein containing a CARD (ASC). This triggers ASC polymerization into helical fibrils and subsequently assembly into micrometer-sized structures known as specks (Masumoto et al., 1999; Franklin et al., 2014; Lu et al., 2014). Caspase-1 is recruited via a caspase recruitment (CARD) domain and this results in caspase-1 autoproteolytic cleavage and activation. Caspase- 1 is then responsible for the cleavage and thus activation of cytokines IL-1 $\beta$ and IL-18, which are released from cells, contributing to inflammation (Figure 2).

The activation of the inflammasome by $A \beta$ fibrils was first shown in vitro and was dependent on $\mathrm{A} \beta$ phagocytosis and the subsequent damage to lysosomes, resulting in the release of cathepsin B into the cytosol (Halle et al., 2008). A further study then demonstrated that when NLRP3 or caspase-1 was 


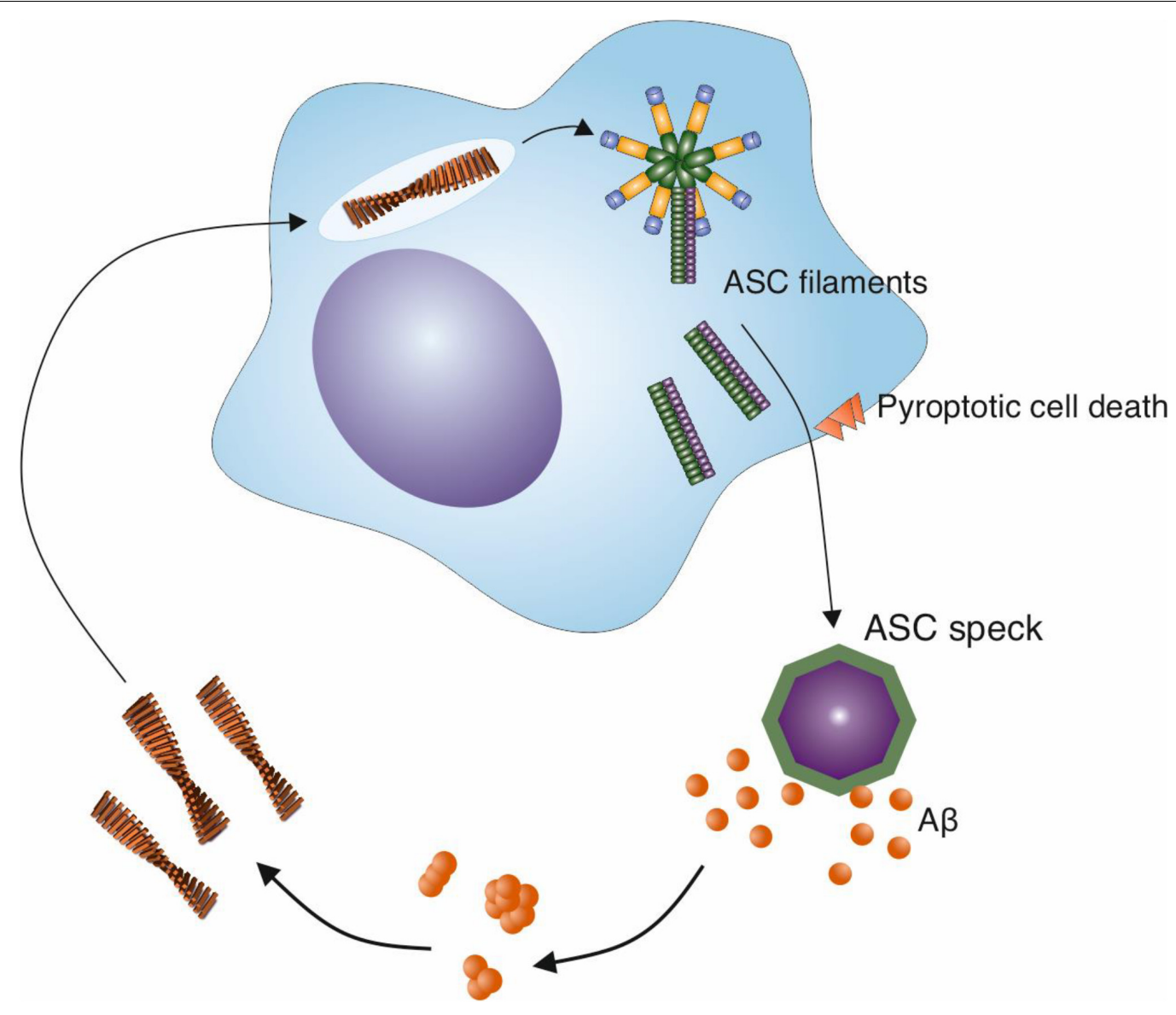

FIGURE 3 | ASC specks released from activated microglia cross-seed A $\beta$ aggregation. The NLRP3 inflammasome is activated in microglia in response to a variety of stimuli, including $A \beta$ fibrils. This activation leads to the release of specks formed from ASC, an adaptor protein that is involved in the inflammasome pathway. ASC specks cross-seed $A \beta$ peptide, resulting in the formation of further $A \beta$ aggregates in the brain and may create a cycle of inflammasome activation and amyloid formation.

knocked out in transgenic AD model mice, IL-1 $\beta$ activation was substantially reduced, providing support for the role of this activation pathway in vivo (Heneka et al., 2013). Furthermore, increased levels of cleaved caspase- 1 were identified in AD patient brains compared with controls in hippocampal and cortical lysates, implicating the NLRP3 inflammasome as an important pathway in disease (Heneka et al., 2013).

Crucially, in addition to the activation of the NLRP3 inflammasome by $\mathrm{A} \beta$ fibrils, evidence is emerging for a positive effect of the NLRP3 inflammasome on A $\beta$ aggregation (Figure 3 ). The activation of the NLRP3 inflammasome results in the release of ASC specks (Swanson et al., 2019). Venegas et al. (2017) demonstrated that after their release, ASC specks bind to $A \beta_{1-42}$ peptide (Venegas et al., 2017). In vitro experiments revealed that ASC specks accelerate the aggregation of both $\mathrm{A} \beta_{1-40}$ and $A \beta_{1-42}$ into oligomers and protofibrils, indicating a crossseeding activity (Venegas et al., 2017). This was dependent on the PYD domain of ASC. Moreover, when purified ASC specks were injected into the hippocampus of $\mathrm{AD}$ model mice, more $\mathrm{A} \beta$ deposits were observed, whereas an anti-ASC-speck antibody was capable of reducing $A \beta$ deposition (Venegas et al., 2017).
This suggests that not only do $\mathrm{A} \beta$ fibrils act as a stimulus to trigger microglial activation, but also that the result of this activation is the formation of $\mathrm{A} \beta$ aggregates, effectively producing a positive feedback loop (Figure 3 ). To compound this, in the presence of ASC-A $\beta$ composites, consisting of $\mathrm{A} \beta$ oligomeric complexes forming in close association with ASC fibrils, the phagocytic clearance of $A \beta$ by microglia was reduced by $35 \%$, and its degradation was reduced (Friker et al., 2020). Thus, the activation of the NLRP3 inflammasome by $A \beta$ fibrils could therefore both increase amyloid formation and reduce its clearance, contributing to the $\mathrm{A} \beta$ deposition observed in $\mathrm{AD}$.

\section{ANTIMICROBIAL AND ANTIVIRAL PROPERTIES OF A $\beta$ AND ITS AGGREGATION}

\section{$A \beta$ Response to Bacteria and Fungi}

Infection may be a co-factor in the aggregation of $\mathrm{A} \beta$ into amyloid fibrils, moreover this may be related to the intrinsic 
antimicrobial activities of $A \beta$ peptides. Indeed, it was found that $A \beta$ inhibits the growth of eight common microorganisms including both bacterial and fungal species, at a similar potency to the bone fide antimicrobial peptide LL-37 (Soscia et al., 2010). A further study reported that $A \beta$ protects against fungal and bacterial infections in mouse, Caenorhabditis elegans and cell culture models (Kumar et al., 2016). This was as a result of $A \beta$ binding to microbial cell wall polysaccharides via its heparin-binding domain (VHHQKL) (Kumar et al., 2016). A $\beta$ oligomers exhibited significantly increased binding compared to the monomeric peptide, and electron microscopy imaging revealed $\mathrm{A} \beta$ fibrillation, with fibrils associating with and linking together microbial cells into clumps, a process known as agglutination (Kumar et al., 2016). Another study found that this microbial agglutination was mediated by $\mathrm{A} \beta_{1-42}$, but not $\mathrm{A} \beta_{1-40}$, suggesting that the more amyloidogenic form of this peptide has greater antimicrobial activity (Spitzer et al., 2016).

The demonstration of the antimicrobial properties of $\mathrm{A} \beta$ suggests that $\mathrm{AD}$ may have an infectious etiology. A relationship has been proposed between gut microbiota and brain amyloidosis. APP AD model mice were found to have an altered gut microbiome compared to wild-type mice, and when APP mice were bred under sterile conditions, a significant reduction in cerebral $\mathrm{A} \beta$ pathology was observed (Harach et al., 2017). Furthermore, fecal transplants from APP mice bred in standard conditions to APP mice bred in sterile conditions resulted in increased $A \beta$ pathology, whereas fecal transplants from wild-type mice did not have this effect (Harach et al., 2017). This research has been supported by studies in humans, with differences identified in the abundance of pro- and anti-inflammatory gut bacterial taxa in patients with brain amyloidosis (Cattaneo et al., 2017). When the bacterial taxonomic composition of fecal samples was compared between $\mathrm{AD}$ patient and control samples, a distinct microbiome composition was identified in AD samples (Vogt et al., 2017). Similarly, a number of studies have suggested a connection between the oral microbiome and AD (Ide et al., 2016; Chen et al., 2017; Dominy et al., 2019). Porphyromonas gingivalis, a pathogen in periodontal infections, was recently identified in $\mathrm{AD}$ brains and resulted in increased $\mathrm{A} \beta$ deposition in mice (Poole et al., 2013; Dominy et al., 2019).

\section{A $\beta$ Response to Viruses}

A number of studies have investigated the relationship between viral infections and $\mathrm{AD}$. There is evidence that herpes simplex virus type-1 (HSV-1) is a risk factor for $\mathrm{AD}$, when the $\mathrm{AD}$ patient is a carrier of the APOE- 44 allele (Itzhaki et al., 1997). Subsequent studies have found an association between HSV-1 and the risk of neurodegenerative disease, with one retrospective cohort study in Taiwan identifying a 2.56-fold increased risk of dementia with HSV infection (Tzeng et al., 2018). However, another study reported only a slightly increased risk (Chen et al., 2018). In addition to HSV-1, analysis of genomic, transcriptomic, proteomic and histopathological data from brains identified increased human herpesvirus 6A (HHV-6A) and human herpesvirus 7 (HHV-7) in AD brain tissue samples compared to controls. Viral abundance was suggested to be linked with APP metabolism networks, including the induction of PSEN1 and BACE1 expression by HHV-6A (Readhead et al., 2018). However, the statistical robustness of this analysis was contested, and re-analysis of the data did not support a link between HHV-6A or HHV-7 and AD (Jeong and Liu, 2019).

Whilst the link between herpesvirus infections and AD may be equivocal, various studies suggest that herpesviruses and other infectious agents promote $\mathrm{A} \beta$ aggregation into amyloid fibrils. In neuronal and glial cell cultures, infection with HSV1 led to the accumulation of $A \beta$ within cells, and increased $A \beta$ deposits were present in mouse brains after HSV-1 infection (Wozniak et al., 2007). Further investigation revealed that in AD, HSV-1 DNA localizes with A $\beta$ plaques, with $90 \%$ of the plaques containing viral DNA (Wozniak et al., 2009). Similarly, it was shown that in a mouse model of recurrent HSV1 infections, $\mathrm{AD}$ pathologies including $\mathrm{A} \beta$ accumulation, tau hyperphosphorylation and markers of neuroinflammation were observed (De Chiara et al., 2019). These results were corroborated recently in a 3D human brain-like model formed from humaninduced neural stem cells (Cairns et al., 2020). It was found that whilst high HSV-1 infection levels led to cell death, low HSV-1 infection levels led to an AD-like phenotype, including dense $\mathrm{A} \beta$ fibrillar plaques and neuroinflammation (Cairns et al., 2020).

Both $A \beta_{1-40}$ and $A \beta_{1-42}$ inhibited the replication of HSV1 in a number of cell lines when added to the cultures either prior to or in parallel with the virus (Bourgade et al., 2014). This effect was postulated to be a result of $\mathrm{A} \beta$ inserting into the HSV-1 envelope (Bourgade et al., 2014). Moreover, A $\beta$ oligomers bind viral surface glycoproteins and fibrils mediate virus entrapment (Eimer et al., 2018). A recent study found that $\mathrm{HSV}-1$ catalyzes the aggregation of $\mathrm{A} \beta_{1-42}$ in vitro and in an $\mathrm{AD}$ mouse model via surface-mediated nucleation, thus providing further support for this hypothesis (Ezzat et al., 2019). Crucially, the interaction of $A \beta$ with viruses may be the same mechanism as its interaction with bacteria and fungi, namely the $\mathrm{A} \beta$ heparinbinding domain binds carbohydrates exposed on the surface of the virus (Eimer et al., 2018).

Not only does $A \beta$ have antiviral activity, but its production may be controlled by the innate immunity protein, interferoninduced transmembrane protein 3 (IFITM3), which upregulates the activity of $\gamma$-secretase, resulting in the increased generation of A $\beta$ peptide (Hur et al., 2020). Furthermore, deletion of IFITM3 in the $5 x F A D$ mouse $\mathrm{AD}$ model resulted in reduced $\mathrm{A} \beta$ plaque formation, and IFITM3 expression was found to increase with aging and in mouse models expressing familial AD genes (Hur et al., 2020). IFITM3 plays a role in preventing viral infection, and its expression is induced by pro-inflammatory cytokines (Bailey et al., 2014). Thus, taken together these data support the antimicrobial and antiviral hypothesis for $\mathrm{A} \beta$ and suggest that infection may be a cofactor for $\mathrm{A} \beta$ aggregation in vivo (Jackson and Hewitt, 2017).

\section{HOW TO PREVENT A $\beta$ AGGREGATION AND ENHANCE REMOVAL OF A $\beta$ DEPOSITS}

$\mathrm{A} \beta$ plaque formation in $\mathrm{AD}$ will be a balance between the rate of amyloid fibril assembly and the rate of clearance. Given 
their potential roles as cofactors in amyloid fibril assembly, targeting microglial activation and infections by viruses and bacteria may represent therapeutic approaches in AD. Similarly, enhancing the uptake and degradation of $A \beta$ fibrils may provide an additional approach to reduce $A \beta$ plaque burden in $\mathrm{AD}$ (Figure 1).

\section{Reducing the Activation of Microglia}

Activated microglia are a characteristic feature of neuroinflammation in AD (Frautschy et al., 1998; Felsky et al., 2019). However, despite a decreased risk of $\mathrm{AD}$ associated with long-term non-steroidal anti-inflammatory drugs (NSAID) treatment, clinical trials of anti-inflammatory drugs to treat $\mathrm{AD}$ have not yet been successful (Aisen et al., 2003; Meyer et al., 2019; Howard et al., 2020). Minocycline, an anti-inflammatory tetracycline capable of crossing the blood-brain barrier (BBB), was found to reduce inflammatory markers and reverse cognitive impairment in an $\mathrm{AD}$-like mouse model, induced by the administration of $\mathrm{A} \beta_{1-42}$ oligomers to the brain (Garcez et al., 2017). However, in clinical trials no improvement in cognitive impairment was identified with minocycline treatment (Howard et al., 2020). Similarly, treatment with naproxen did not slow disease progression in patients with mild-moderate, or reduce the progression of pre-symptomatic AD (Aisen et al., 2003; Meyer et al., 2019).

Whilst the aforementioned anti-inflammatories may be ineffective in the treatment of $\mathrm{AD}$, the inflammasome may prove to be a better target. Indeed, a small molecule inhibitor of the NLRP3 inflammasome, MCC950, was found to stimulate $\mathrm{A} \beta$ phagocytosis in vitro, and reduce $\mathrm{A} \beta$ deposition in $\mathrm{AD}$ (APP/PS1) model mice (Dempsey et al., 2017). This was also associated with an improvement in cognitive function (Dempsey et al., 2017). Similarly, MCC950 prevented $\alpha$-synuclein aggregate pathology and the degeneration of dopaminergic neurons in multiple rodent models of Parkinson's disease (Gordon et al., 2018). These results are supported by a study in which NLRP3 components were knocked out in $A D$ model mice, and this led to enhanced $A \beta$ clearance and decreased A $\beta$ deposition (Heneka et al., 2013). Importantly, these results support the clinical development of inflammasome inhibitors as a treatment for neurodegenerative amyloid diseases such as AD.

\section{Targeting Viral and Bacterial Infections}

The demonstration that $A \beta$ interacts with viruses may provide new routes of clinical intervention in $\mathrm{AD}$ patients; targeting viral infection could prevent the $A \beta$ aggregation associated with AD. Two population cohort studies found that those taking anti-herpetic treatments for HSV infections had a reduced risk of dementia (Chen et al., 2018; Tzeng et al., 2018). In addition, in a recent study in 3D brain-like structures, HSV-1 infection induced an AD-like phenotype, and antiviral medication was successful in abrogating this phenotype, suggesting that antivirals could be utilized to treat AD patients (Cairns et al., 2020). An antiviral drug, Valacyclovir, is currently in Phase II clinical trials for the treatment of
AD (ClinicalTrials.gov, ID\# NCT03282916). Similarly, targeting bacterial infections could be used to prevent $A \beta$ aggregation in AD. For example, inhibition of gingipains, toxic proteases from $P$. gingivalis, using small molecule inhibitors led to reduced $A \beta_{1-42}$ production, neuroinflammation and neuronal death (Dominy et al., 2019). Consequently, a small molecule inhibitor of gingipains, COR388, is currently in Phase II clinical trials for the treatment of $\mathrm{AD}$ (ClinicalTrials.gov, ID\# NCT03823404).

\section{Enhancing the Uptake and Degradation of Amyloid by Microglia}

Whilst a role for TLR receptors in $A \beta$ uptake by microglia has been suggested, these receptors also have a central role in the activation of inflammation (Reed-Geaghan et al., 2009; Stewart et al., 2010). Thus, targeting these receptors in the treatment of $\mathrm{AD}$ is not straight forward, as a detrimental inflammatory response could also be activated. Treatment with an LPS-derived TLR4 agonist, monophosphoryl lipid A (MPL) in a murine $\mathrm{AD}$ model led to reduced $\mathrm{A} \beta$ load and enhanced cognitive function, but a 'low level' inflammatory response was also triggered (Michaud et al., 2013). However, the AAV-mediated expression of the human TLR5 ectodomain as a 'decoy' receptor was explored, and found to result in the attenuation of $\mathrm{A} \beta$ plaque formation in a mouse model (Chakrabarty et al., 2018). The human TLR5 ectodomain was fused to human IgG4 Fc (sTLR5Fc), and this was found to bind to $A \beta$ fibrils strongly, and to other forms of $A \beta_{1-40}$ and $A \beta_{1-42}$, to lesser extents. Therefore, the reduction in $A \beta$ deposition into plaques could be due to the sequestration of fibrils by the TLR5 ectodomain (Chakrabarty et al., 2018). Furthermore, in vitro incubation with sTLR5Fc resulted in increased uptake of $A \beta_{1-40}$ fibrils by microglia without activating TLR5 signaling (Chakrabarty et al., 2018), thus suggesting it as a safe method of immunomodulation in $\mathrm{AD}$.

TREM2 is upregulated in response to increased $A \beta$ levels in an AD mouse model (Jiang et al., 2014). Importantly, upregulating TREM2 significantly reduced $\mathrm{A} \beta$ deposition, neuroinflammation, synapse loss and led to improvements in cognitive function (Jiang et al., 2014). A monoclonal antibody targeting TREM2, AL002a, was found to activate TREM2 signaling in vitro (Price et al., 2020). Furthermore, treatment of $5 \mathrm{xFAD}$ mice with this antibody led to increased microglial recruitment to $A \beta$ plaques, and reduced $A \beta$ deposition (Price et al., 2020). TREM2 could therefore be a potential target for clinical intervention in the treatment of $\mathrm{AD}$, and AL002 is currently being tested in Phase I clinical trials in patients with mild to moderate Alzheimer's disease (ClinicalTrials.gov, ID\#NCT03635047). Another monoclonal antibody, 4D9, was recently found to increase microglial uptake of $A \beta$ in vitro and reduce $A \beta$ deposits in the APP NL-GF knock-in AD mouse model (Schlepckow et al., 2020). This antibody enhances TREM2 activity by competing for binding to the $\alpha$-secretase cleavage site, therefore preventing TREM2 cleavage and subsequent shedding, whilst also enhancing TREM2 signaling (Schlepckow et al., 2020). 
Macrophage colony stimulating factor (M-CSF) upregulates the transcription of the chloride transporter CIC-7 by microglia, increasing lysosomal acidification and enhancing the degradation of $\mathrm{A} \beta$ amyloid fibrils (Majumdar et al., 2011). This suggests that M-CSF could be used to promote $\mathrm{A} \beta$ amyloid clearance in $\mathrm{AD}$. Indeed, in $\mathrm{APP}_{(\mathrm{Swe})} / \mathrm{PS} 1$ transgenic AD model mice M-CSF treatment resulted in a reduced number of $A \beta$ deposits, a higher ratio of microglia with evidence of $A \beta$ internalization, and reduced cognitive decline (Boissonneault et al., 2009). However, M-CSF is a hematopoietic cytokine that has been implicated in a number of inflammatory and autoimmune diseases and as a consequence M-CSF treatment could have deleterious inflammatory effects (Hamilton et al., 2016).

An alternative to enhancing pathways for fibril uptake and degradation is to inhibit negative regulators of these pathways. Evidence points toward a role for CD33 as a negative modulator of A $\beta$ fibril clearance (Bradshaw et al., 2013; Griciuc et al., 2013, 2019), and inhibition of CD33 may represent a therapeutic strategy. A phase I clinical trial is underway for the monoclonal antibody, AL003, which targets and inhibits CD33 (ClinicalTrials.gov, NCT03822208). With evidence suggesting that $\mathrm{CD} 33$ deletion in mice reduces $\mathrm{A} \beta$ pathology and increases microglial expression of genes relating to phagocytosis, AL003 administration aims to inhibit $\mathrm{CD} 33$, thus increasing the clearance activity of microglia and reducing $A \beta$ deposition (Griciuc et al., 2019). Similarly, CD22 could be targeted in AD. A recent study used CRISPR-Cas9 with RNA sequencing analysis to identify genes that are related to aging and lead to changes in microglial phagocytosis (Pluvinage et al., 2019). CD22 was identified as a receptor that negatively regulates phagocytosis and is upregulated in aged microglia. It was found that inhibiting CD22 with a CD22 blocking antibody improved the phagocytosis of $A \beta$ oligomers and $\alpha$-synuclein fibrils in vivo, supporting the hypothesis that $\mathrm{AD}$ results from age-related changes in microglia that reduce their amyloid clearing ability (Pluvinage et al., 2019). Similarly, manipulating microglia in order to favor a switch from dysfunctional phenotypes to a protective phenotype such as DAM could be a used as future approach to restore microglial function and enhance the clearance of Keren-Shaul et al. (2017); Krasemann et al. (2017), and Marschallinger et al. (2020).

\section{DISCUSSION}

Multiple different cofactors may influence $\mathrm{A} \beta$ assembly in vivo, including inflammation and infection. Moreover, the extent of amyloid plaques formation in $\mathrm{AD}$ will be dependent on the balance between $A \beta$ fibril formation and the clearance and degradation of these deposits. Evidence points to microglia playing roles in both amyloid formation and its clearance (Lee and Landreth, 2010; Venegas et al., 2017), as such the balance between these microglial activities may be a factor in the accumulation of amyloid plaques. Yet, despite their recruitment to plaques, microglia do not appear to be able to halt the formation $A \beta$ fibrils in $A D$. In the aging $A D$ brain a reduction in the uptake and degradation of $\mathrm{A} \beta$ amyloid fibrils by microglia may cause these cells to be overwhelmed by the amyloid deposits (Hickman et al., 2008; Mawuenyega et al., 2010; Krabbe et al., 2013). Enhancement of the degradative activity of microglia therefore represent potential targets for therapeutic intervention in AD (Boissonneault et al., 2009; Majumdar et al., 2011).

Neuroinflammation is a damaging process in AD (Heppner et al., 2015), but via production of the inflammasome specks microglia could be exacerbating the disease by cross seeding $A \beta$ amyloid formation (Venegas et al., 2017). Moreover, $A \beta$ fibrils can themselves stimulate inflammasome formation and this raises the intriguing possibility that $\mathrm{A} \beta$ fibrils promote $\mathrm{A} \beta$ aggregation via microglia activation, resulting in a vicious cycle (Halle et al., 2008; Heneka et al., 2013; Venegas et al., 2017; Friker et al., 2020). As such the inflammasome may be a good target for $\mathrm{AD}$ therapeutics (Heneka et al., 2013; Dempsey et al., 2017; Gordon et al., 2018), as both inflammation and inflammasome-dependent $A \beta$ fibril assembly could be reduced.

Whilst, $A \beta$ aggregation has been thought of as being a pathological process, $A \beta$ has properties consistent with it being an antimicrobial peptide (Soscia et al., 2010; Bourgade et al., 2014; Kumar et al., 2016; Spitzer et al., 2016; Hur et al., 2020). Indeed, there are a number of key similarities with the antimicrobial peptide LL-37, which can also assemble into amyloid fibrils (Sood et al., 2008; Jackson and Hewitt, 2017). Whilst a role for $A \beta$ in vivo as an antimicrobial peptide is unclear, in vitro it can agglutinate viruses, bacteria and fungi by assembling into amyloid like structures on the surface of these infectious agents. This provides an additional mechanism by which $A \beta$ assembly could be promoted in vivo, by virtue of its interaction with the surfaces of infectious agents (Kumar et al., 2016; Eimer et al., 2018; Ezzat et al., 2019). Moreover, infection would also be predicted to activate inflammation and could promote $\mathrm{A} \beta$ aggregation via the inflammasome (Swanson et al., 2019). Although, bacteria, fungi, viruses and inflammasome specks can cross seed $A \beta$ aggregation, little is known about the structure and properties of the fibrils produced. Crucially, both in vitro and in vivo $\mathrm{A} \beta$ fibrils can assemble into multiple different fibril polymorphs, in which the $A \beta$ peptides have different arrangements in the fibril structure (Petkova et al., 2005; Paravastu et al., 2008, 2009; Lu et al., 2013; Colvin et al., 2015; Gremer et al., 2017; Kollmer et al., 2019). Little is known about the molecular structure of the $\mathrm{A} \beta$ aggregates produced by cross seeding by either specks and microorganisms in vitro nor how they relate to those formed in vivo in $\mathrm{AD}$ brain. This is important to know because $\mathrm{A} \beta$ fibril polymorphism in vivo is related to the type of $\mathrm{AD}$ presented (Lu et al., 2013; Qiang et al., 2017; Rasmussen et al., 2017). Similarly, whilst A $\beta$ fibrils can be internalized and degraded by microglia, at least to some extent in vitro (Husemann et al., 2001; Tahara et al., 2006; Reed-Geaghan et al., 2009; Song et al., 2011) it is not known if polymorphism affects clearance of amyloid fibrils in vivo. It is plausible that $A \beta$ fibril polymorphism could affect the affinity for microglial $A \beta$ receptors and how the fibrils are degraded by microglial 
proteases. Thus, any fibril polymorphs that can escape microglial clearance may accumulate more in an AD brain.

In summary, in vivo multiple different cofactors, including microglia and infection, may influence the assembly of $A \beta$ amyloid fibrils, and thus could represent targets for therapeutic intervention in $\mathrm{AD}$.

\section{AUTHOR CONTRIBUTIONS}

$\mathrm{MB}, \mathrm{EH}$, and SR wrote and edited the manuscript. All authors contributed to the article and approved the submitted version.

\section{REFERENCES}

Aisen, P. S., Schafer, K. A., Grundman, M., Pfeiffer, E., Sano, M., Davis, K. L., et al. (2003). Effects of Rofecoxib or Naproxen vs placebo on alzheimer disease progression: a randomized controlled trial. J. Am. Med. Assoc. 289, 2819-2826. doi: 10.1001/jama.289.21.2819

Ajami, B., Bennett, J. L., Krieger, C., Tetzlaff, W., and Rossi, F. M. V. (2007). Local self-renewal can sustain CNS microglia maintenance and function throughout adult life. Nat. Neurosci. 10, 1538-1543. doi: 10.1038/nn2014

Bailey, C. C., Zhong, G., Huang, I.-C., and Farzan, M. (2014). IFITM-Family proteins: the cell's first line of antiviral defense. Annu. Rev. Virol. 1, 261-283. doi: 10.1146/annurev-virology-031413-085537

Bales, K. R., Verina, T., Dodel, R. C., Du, Y., Altstiel, L., Bender, M., et al. (1997). Lack of apolipoprotein $\mathrm{E}$ dramatically reduces amyloid $\beta$-peptide deposition. Nat. Genet. 17, 263-264. doi: 10.1038/ng1197-263

Bamberger, M. E., Harris, M. E., McDonald, D. R., Husemann, J., and Landreth, G. E. (2003). A cell surface receptor complex for fibrillar $\beta$-amyloid mediates microglial activation. J. Neurosci. 23, 2665-2674. doi: 10.1523/JNEUROSCI.2307-02665.2003

Bauer, J., Strauss, S., Schreiter-Gasser, U., Ganter, U., Schlegel, P., Witt, I., et al. (1991). Interleukin-6 and $\alpha$-2-macroglobulin indicate an acute-phase state in Alzheimer's disease cortices. FEBS Lett. 285, 111-114. doi: 10.1016/00145793(91)80737-N

Bauernfeind, F. G., Horvath, G., Stutz, A., Alnemri, E. S., MacDonald, K., Speert, D., et al. (2009). Cutting Edge: NF- $\kappa$ B activating pattern recognition and cytokine receptors license NLRP3 inflammasome activation by regulating NLRP3 expression. J. Immunol. 183, 787-791. doi: 10.4049/jimmunol.0901363

Boissonneault, V., Filali, M., Lessard, M., Relton, J., Wong, G., and Rivest, S. (2009). Powerful beneficial effects of macrophage colony-stimulating factor on $\beta$-amyloid deposition and cognitive impairment in Alzheimers disease. Brain 132, 1078-1092. doi: 10.1093/brain/awn331

Bourgade, K., Garneau, H., Giroux, G., Le Page, A. Y., Bocti, C., Dupuis, G., et al. (2014). $\beta$-Amyloid peptides display protective activity against the human Alzheimer's disease-associated herpes simplex virus-1. Biogerontology 16, 8598. doi: 10.1007/s10522-014-9538-8

Braak, H., and Braak, E. (1991). Neuropathological stageing of Alzheimer-related changes. Acta Neuropathol. 82, 239-259. doi: 10.1007/BF00308809

Bradshaw, E. M., Chibnik, L. B., Keenan, B. T., Ottoboni, L., Raj, T., Tang, A., et al. (2013). CD33 Alzheimer's disease locus: altered monocyte function and amyloid biology. Nat. Neurosci. 16, 848-850. doi: 10.1038/nn.3435

$\mathrm{Bu}, \mathrm{G}$. (2009). Apolipoprotein e and its receptors in Alzheimer's disease: pathways, pathogenesis and therapy. Nat. Rev. Neurosci. 10, 333-344. doi: 10.1038/ nrn2620

Cairns, D. M., Rouleau, N., Parker, R. N., Walsh, K. G., Gehrke, L., and Kaplan, D. L. (2020). A 3D human brain-like tissue model of herpes-induced Alzheimer's disease. Sci. Adv. 6:eaay8828. doi: 10.1126/sciadv.aay8828

Castellano, J. M., Kim, J., Stewart, F. R., Jiang, H., DeMattos, R. B., Patterson, B. W., et al. (2011). Human apoE isoforms differentially regulate brain amyloid$\beta$ peptide clearance. Sci. Transl. Med. 3:89ra57. doi: 10.1126/scitranslmed. 3002156

Cattaneo, A., Cattane, N., Galluzzi, S., Provasi, S., Lopizzo, N., Festari, C., et al. (2017). Association of brain amyloidosis with pro-inflammatory gut bacterial

\section{FUNDING}

MB was supported by a studentship from the MRC Discovery Medicine North (DiMeN) Doctoral Training Partnership (MR/N013840/1). SR acknowledges funding from the Wellcome Trust (204963).

\section{ACKNOWLEDGMENTS}

We thank members of the Hewitt and Radford laboratories for insightful discussions.

taxa and peripheral inflammation markers in cognitively impaired elderly. Neurobiol. Aging 49, 60-68. doi: 10.1016/j.neurobiolaging.2016.08.019

Chakrabarty, P., Li, A., Ladd, T. B., Strickland, M. R., Koller, E. J., Burgess, J. D., et al. (2018). TLR5 decoy receptor as a novel anti-amyloid therapeutic for Alzheimer's disease. J. Exp. Med. 215, 2247-2264. doi: 10.1084/jem.20180484

Chen, C. K., Wu, Y. T., and Chang, Y. C. (2017). Association between chronic periodontitis and the risk of Alzheimer's disease: a retrospective, populationbased, matched-cohort study. Alzheimers Res. Ther. 9:56.

Chen, V. C. H., Wu, S. I., Huang, K. Y., Yang, Y. H., Kuo, T. Y., Liang, H. Y., et al. (2018). Herpes zoster and dementia: a nationwide population-based cohort study. J. Clin. Psychiatry 79:16m11312. doi: 10.4088/JCP.16m11312

Chih Jin, S., Benitez, B. A., Karch, C. M., Cooper, B., Skorupa, T., Carrell, D., et al. (2014). Coding variants in TREM2 increase risk for Alzheimer's disease. Hum. Mol. Genet. 23, 5838-5846. doi: 10.1093/hmg/ddu277

Christie, R. H., Freeman, M., and Hyman, B. T. (1996). Expression of the macrophage scavenger receptor, a multifunctional lipoprotein receptor, in microglia associated with senile plaques in Alzheimer's disease. Am. J. Pathol. 148, 399-403.

Cohen, S. I. A., Linse, S., Luheshi, L. M., Hellstrand, E., White, D. A., Rajah, L., et al. (2013). Proliferation of amyloid- $\beta 42$ aggregates occurs through a secondary nucleation mechanism. Proc. Natl. Acad. Sci. U.S.A. 110, 9758-9763. doi: $10.1073 /$ pnas. 1218402110

Colvin, M. T., Silvers, R., Frohm, B., Su, Y., Linse, S., and Griffin, R. G. (2015). High Resolution Structural Characterization of A $\beta 42$ Amyloid Fibrils by Magic Angle Spinning NMR. J. Am. Chem. Soc. 137, 7509-7518. doi: 10.1021/jacs.5b03997

Condello, C., Yuan, P., Schain, A., and Grutzendler, J. (2015). Microglia constitute a barrier that prevents neurotoxic protofibrillar $A \beta 42$ hotspots around plaques. Nat. Commun. 6:6176. doi: 10.1038/ncomms7176

Coraci, I. S., Husemann, J., Berman, J. W., Hulette, C., Dufour, J. H., Campanella, G. K., et al. (2002). CD36, a class B scavenger receptor, is expressed on microglia in Alzheimer's disease brains and can mediate production of reactive oxygen species in response to $\beta$-amyloid fibrils. Am. J. Pathol. 160, 101-112. doi: 10.1016/s0002-9440(10)64354-4

Davalos, D., Grutzendler, J., Yang, G., Kim, J. V., Zuo, Y., Jung, S., et al. (2005). ATP mediates rapid microglial response to local brain injury in vivo. Nat. Neurosci. 8, 752-758. doi: 10.1038/nn1472

De Chiara, G., Piacentini, R., Fabiani, M., Mastrodonato, A., Marcocci, M. E., Limongi, D., et al. (2019). Recurrent herpes simplex virus-1 infection induces hallmarks of neurodegeneration and cognitive deficits in mice. PLoS Pathog. 15:e1007617. doi: 10.1371/journal.ppat.1007617

Dempsey, C., Rubio Araiz, A., Bryson, K. J., Finucane, O., Larkin, C., Mills, E. L., et al. (2017). Inhibiting the NLRP3 inflammasome with MCC950 promotes non-phlogistic clearance of amyloid- $\beta$ and cognitive function in APP/PS1 mice. Brain Behav. Immun. 61, 306-316. doi: 10.1016/j.bbi.2016.12.014

Dominy, S. S., Lynch, C., Ermini, F., Benedyk, M., Marczyk, A., Konradi, A., et al. (2019). Porphyromonas gingivalis in Alzheimer's disease brains: evidence for disease causation and treatment with small-molecule inhibitors. Sci. Adv. 5:eaau3333. doi: 10.1126/sciadv.aau3333

Eanes, E. D., and Glenner, G. G. (1968). X-ray diffraction studies on amyloid filaments. J. Histochem. Cytochem. 16, 673-677. doi: 10.1177/16.11.673

Eimer, W. A., Vijaya Kumar, D. K., Navalpur Shanmugam, N. K., Rodriguez, A. S., Mitchell, T., Washicosky, K. J., et al. (2018). Alzheimer's disease-associated 
$\beta$-amyloid is rapidly seeded by herpesviridae to protect against brain infection. Neuron 99, 56-63.e3. doi: 10.1016/j.neuron.2018.06.030

El Khoury, J., Hickman, S. E., Thomas, C. A., Cao, L., Silverstein, S. C., and Loike, J. D. (1996). Scavenger receptor-mediated adhesion of microglia to $\beta$-amyloid fibrils. Nature 382, 716-719. doi: 10.1038/382716a0

Evangelisti, E., Cascella, R., Becatti, M., Marrazza, G., Dobson, C. M., Chiti, F., et al. (2016). Binding affinity of amyloid oligomers to cellular membranes is a generic indicator of cellular dysfunction in protein misfolding diseases. Sci. Rep. 6:32721. doi: 10.1038/srep32721

Ezzat, K., Pernemalm, M., Pålsson, S., Roberts, T. C., Järver, P., Dondalska, A., et al. (2019). The viral protein corona directs viral pathogenesis and amyloid aggregation. Nat. Commun. 10:2331.

Farris, W., Mansourian, S., Chang, Y., Lindsley, L., Eckman, E. A., Frosch, M. P., et al. (2003). Insulin-degrading enzyme regulates the levels of insulin, amyloid $\beta$-protein, and the $\beta$-amyloid precursor protein intracellular domain in vivo. Proc. Natl. Acad. Sci. U.S.A. 100, 4162-4167. doi: 10.1073/pnas.0230450100

Fassbender, K., Walter, S., Kühl, S., Landmann, R., Ishii, K., Bertsch, T., et al. (2004). The LPS receptor (CD14) links innate immunity with Alzheimer's disease. FASEB J. 18, 203-205. doi: 10.1096/fj.03-0364fje

Felsky, D., Roostaei, T., Nho, K., Risacher, S. L., Bradshaw, E. M., Petyuk, V., et al. (2019). Neuropathological correlates and genetic architecture of microglial activation in elderly human brain. Nat. Commun. 10:409.

Franchi, L., Eigenbrod, T., and Núñez, G. (2009). Cutting Edge: TNF- $\alpha$ Mediates Sensitization to ATP and Silica via the NLRP3 Inflammasome in the Absence of Microbial Stimulation. J. Immunol. 183, 792-796. doi: 10.4049/jimmunol. 0900173

Franklin, B. S., Bossaller, L., De Nardo, D., Ratter, J. M., Stutz, A., Engels, G., et al. (2014). The adaptor ASC has extracellular and "prionoid" activities that propagate inflammation. Nat. Immunol. 15, 727-737. doi: 10.1038/ni.2913

Frautschy, S. A., Yang, F., Irrizarry, M., Hyman, B., Saido, T. C., Hsiao, K., et al. (1998). Microglial response to amyloid plaques in APPsw transgenic mice. Am. J. Pathol. 152, 307-317.

Frigerio, C. S., Wolfs, L., Fattorelli, N., Perry, V. H., Fiers, M., and De Strooper, B. (2019). The major risk factors for alzheimer's disease: age, sex, and genes modulate the microglia response to Abeta Plaques. Cell Rep. 27, 1293-1306.e6. doi: 10.1016/j.celrep.2019.03.099

Friker, L. L., Scheiblich, H., Hochheiser, I. V., Latz, E., Geyer, M., and Heneka, M. T. (2020). $\beta$-Amyloid Clustering around ASC fibrils boosts its toxicity in microglia. Cell Rep. 30, 3743-3754.e6. doi: 10.1016/j.celrep.2020.02.025

Garcez, M. L., Mina, F., Bellettini-Santos, T., Carneiro, F. G., Luz, A. P., Schiavo, G. L., et al. (2017). Minocycline reduces inflammatory parameters in the brain structures and serum and reverses memory impairment caused by the administration of amyloid $\beta$ (1-42) in mice. Prog. Neuropsychopharmacol. Biol. Psychiatry 77, 23-31. doi: 10.1016/j.pnpbp.2017.03.010

Ginhoux, F., Greter, M., Leboeuf, M., Nandi, S., See, P., Gokhan, S., et al. (2010). Fate mapping analysis reveals that adult microglia derive from primitive macrophages. Science 330, 841-845. doi: 10.1126/science.1194637

Gordon, R., Albornoz, E. A., Christie, D. C., Langley, M. R., Kumar, V., Mantovani, S., et al. (2018). Inflammasome inhibition prevents -synuclein pathology and dopaminergic neurodegeneration in mice. Sci. Transl. Med. 10:eaah4066. doi: 10.1126/scitranslmed.aah4066

Gremer, L., Schölzel, D., Schenk, C., Reinartz, E., Labahn, J., Ravelli, R. B. G., et al. (2017). Fibril structure of amyloid-beta(1-42) by cryo - electron microscopy. Science 358, 116-119. doi: 10.1042/BJ20081572

Griciuc, A., Patel, S., Federico, A. N., Choi, S. H., Innes, B. J., Oram, M. K., et al. (2019). TREM2 Acts downstream of CD33 in MODULATING MICROGLIAL PAThology in Alzheimer's Disease. Neuron 103, 820-835.e7. doi: 10.1016/j. neuron.2019.06.010

Griciuc, A., Serrano-Pozo, A., Parrado, A. R., Lesinski, A. N., Asselin, C. N., Mullin, K., et al. (2013). Alzheimer's disease risk gene cd33 inhibits microglial uptake of amyloid beta. Neuron 78, 631-643. doi: 10.1016/j.neuron.2013.04.014

Griffin, W. S. T., Stanley, L. C., Ling, C., White, L., MacLeod, V., Perrot, L. J., et al. (1989). Brain interleukin 1 and S-100 immunoreactivity are elevated in Down syndrome and Alzheimer disease. Proc. Natl. Acad. Sci. U.S.A. 86, 7611-7615. doi: $10.1073 /$ pnas.86.19.7611

Halle, A., Hornung, V., Petzold, G. C., Stewart, C. R., Monks, B. G., Reinheckel, T., et al. (2008). The NALP3 inflammasome is involved in the innate immune response to amyloid- $\beta$. Nat. Immunol. 9, 857-865. doi: 10.1038/ni.1636
Hamerman, J. A., Jarjoura, J. R., Humphrey, M. B., Nakamura, M. C., Seaman, W. E., and Lanier, L. L. (2006). Cutting Edge: inhibition of TLR and FcR Responses in Macrophages by Triggering Receptor Expressed on Myeloid Cells (TREM)-2 and DAP12. J. Immunol. 177, 2051-2055. doi: 10.4049/jimmunol. 177.4.2051

Hamerman, J. A., Tchao, N. K., Lowell, C. A., and Lanier, L. L. (2005). Enhanced Toll-like receptor responses in the absence of signaling adaptor DAP12. Nat. Immunol. 6, 579-586. doi: 10.1038/ni1204

Hamilton, J. A., Cook, A. D., and Tak, P. P. (2016). Anti-colony-stimulating factor therapies for inflammatory and autoimmune diseases. Nat. Rev. Drug Discov. 16, 53-70. doi: $10.1038 / \mathrm{nrd} .2016 .231$

Hara, M., Matsushima, T., Satoh, H., Iso-o, N., Noto, H., Togo, M., et al. (2003). Isoform-dependent cholesterol efflux from macrophages by apolipoprotein $\mathrm{E}$ is modulated by cell surface proteoglycans. Arterioscler. Thromb. Vasc. Biol. 23, 269-274. doi: 10.1161/01.ATV.0000054199.78458.4B

Harach, T., Marungruang, N., Duthilleul, N., Cheatham, V., Mc Coy, K. D., Frisoni, G., et al. (2017). Reduction of Abeta amyloid pathology in APPPS1 transgenic mice in the absence of gut microbiota. Sci. Rep. 7:41802. doi: 10.1038/srep 41802

Heckmann, B. L., Teubner, B. J. W., Tummers, B., Boada-Romero, E., Harris, L., Yang, M., et al. (2019). LC3-Associated Endocytosis Facilitates $\beta$-Amyloid Clearance and Mitigates Neurodegeneration in Murine Alzheimer's Disease. Cell 178, 536-551.e14. doi: 10.1016/j.cell.2019.05.056

Heneka, M. T., Kummer, M. P., Stutz, A., Delekate, A., Schwartz, S., Vieira-Saecker, A., et al. (2013). NLRP3 is activated in Alzheimer's disease and contributes to pathology in APP/PS1 mice. Nature 493, 674-678. doi: 10.1038/nature11729

Heppner, F. L., Ransohoff, R. M., and Becher, B. (2015). Immune attack: the role of inflammation in Alzheimer disease. Nat. Rev. Neurosci. 16, 358-372. doi: $10.1038 / \mathrm{nrn} 3880$

Hickman, S. E., Allison, E. K., and El Khoury, J. (2008). Microglial dysfunction and defective $\beta$-amyloid clearance pathways in aging alzheimer's disease mice. J. Neurosci. 28, 8354-8360. doi: 10.1523/JNEUROSCI.0616-08.2008

Hollingworth, P., Harold, D., Sims, R., Gerrish, A., Lambert, J. C., Carrasquillo, M. M., et al. (2011). Common variants at ABCA7, MS4A6A/MS4A4E, EPHA1, $\mathrm{CD} 33$ and CD2AP are associated with Alzheimer's disease. Nat. Genet. 43, 429-436. doi: 10.1038/ng.803

Howard, R., Zubko, O., Bradley, R., Harper, E., Pank, L., O’Brien, J., et al. (2020). Minocycline at 2 Different Dosages vs Placebo for Patients with Mild Alzheimer disease: a randomized clinical trial. JAMA Neurol. 77, 164-174. doi: 10.1001/ jamaneurol.2019.3762

Hsieh, C. L., Koike, M., Spusta, S. C., Niemi, E. C., Yenari, M., Nakamura, M. C., et al. (2009). A role for TREM2 ligands in the phagocytosis of apoptotic neuronal cells by microglia. J. Neurochem. 109, 1144-1156. doi: 10.1111/j.14714159.2009.06042.x

Hur, J. Y., Frost, G. R., Wu, X., Crump, C., Pan, S. J., Wong, E., et al. (2020). The innate immunity protein IFITM3 modulates $\gamma$-secretase in Alzheimer's disease. Nature 586, 735-740. doi: 10.1038/s41586-020-2681-2

Husemann, J., Loike, J. D., Kodama, T., and Silverstein, S. C. (2001). Scavenger receptor class B type I (SR-BI) mediates adhesion of neonatal murine microglia to fibrillar beta-amyloid. J. Neuroimmunol. 114, 142-150. doi: 10.1016/s01655728(01)00239-9

Iadanza, M. G., Jackson, M. P., Hewitt, E. W., Ranson, N. A., and Radford, S. E. (2018). A new era for understanding amyloid structures and disease. Nat. Rev. Mol. Cell Biol. 19, 755-773. doi: 10.1038/s41580-018-0060-8

Ide, M., Harris, M., Stevens, A., Sussams, R., Hopkins, V., Culliford, D., et al. (2016). Periodontitis and cognitive decline in Alzheimer's disease. PLoS One 11:e0151081. doi: 10.1371/journal.pone.0151081

Itagaki, S., McGeer, P. L., Akiyama, H., Zhu, S., and Selkoe, D. (1989). Relationship of microglia and astrocytes to amyloid deposits of Alzheimer disease. J. Neuroimmunol. 24, 173-182. doi: 10.1016/0165-5728(89)90115-X

Itzhaki, R. F., Lin, W. R., Shang, D., Wilcock, G. K., Faragher, B., and Jamieson, G. A. (1997). Herpes simplex virus type 1 in brain and risk of Alzheimer's disease. Lancet 349, 241-244. doi: 10.1016/s0140-6736(96)10149-5

Jack, C. R., Petersen, R. C., Xu, Y., O'brien, P. C., Smith, G. E., Ivnik, R. J., et al. (1998). The rate of medial temporal lobe atrophy in typical aging and Alzheimer's disease. Neurology 51:993-999. doi: 10.1212/wnl.51.4.993

Jackson, M. P., and Hewitt, E. W. (2017). Why are functional amyloids non-toxic in humans? Biomolecules 7:71. doi: 10.3390/biom7040071 
Jansen, I. E., Savage, J. E., Watanabe, K., Bryois, J., Williams, D. M., Steinberg, S., et al. (2019). Genome-wide meta-analysis identifies new loci and functional pathways influencing Alzheimer's disease risk. Nat. Genet. 51, 404-413.

Jeong, H. H., and Liu, Z. (2019). Are HHV-6A and HHV-7 Really More Abundant in Alzheimer's Disease? Neuron 104, 1034-1035. doi: 10.1016/j.neuron.2019.11. 009

Jiang, Q., Lee, C. Y. D., Mandrekar, S., Wilkinson, B., Cramer, P., Zelcer, N., et al. (2008). ApoE Promotes the Proteolytic Degradation of A $\beta$. Neuron 58, 681-693. doi: 10.1016/j.neuron.2008.04.010

Jiang, T., Tan, L., Zhu, X. C., Zhang, Q. Q., Cao, L., Tan, M. S., et al. (2014). Upregulation of TREM2 ameliorates neuropathology and rescues spatial cognitive impairment in a transgenic mouse model of Alzheimer's disease. Neuropsychopharmacology 39, 2949-2962. doi: 10.1038/npp.2014.164

Jonsson, T., Stefansson, H., Steinberg, S., Jonsdottir, I., Jonsson, P. V., Snaedal, J., et al. (2013). Variant of TREM2 associated with the risk of Alzheimer's disease. N. Engl. J. Med. 368, 107-116. doi: 10.1056/NEJMoa1211103

Kanemitsu, H., Tomiyama, T., and Mori, H. (2003). Human neprilysin is capable of degrading amyloid $\beta$ peptide not only in the monomeric form but also the pathological oligomeric form. Neurosci. Lett. 350, 113-116. doi: 10.1016/S03043940(03)00898-X

Karch, C. M., Cruchaga, C., and Goate, A. M. (2014). Alzheimer's disease genetics: from the bench to the clinic. Neuron 83, 11-26. doi: 10.1016/j.neuron.2014.05. 041

Karch, C. M., Jeng, A. T., Nowotny, P., Cady, J., Cruchaga, C., and Goate, A. M. (2012). Expression of novel Alzheimer's disease risk genes in control and Alzheimer's disease brains. PLoS One 7:e50976. doi: 10.1371/journal.pone. 0050976

Kawasaki, T., and Kawai, T. (2014). Toll-like receptor signaling pathways. Front. Immunol. 5:461. doi: 10.3389/fimmu.2014.00461

Keren-Shaul, H., Spinrad, A., Weiner, A., Matcovitch-Natan, O., Dvir-Szternfeld, R., Ulland, T. K., et al. (2017). A Unique microglia type associated with restricting development of Alzheimer's disease. Cell 169, 1276-1290.e17. doi: 10.1016/j.cell.2017.05.018

Kidana, K., Tatebe, T., Ito, K., Hara, N., Kakita, A., Saito, T., et al. (2018). Loss of kallikrein-related peptidase 7 exacerbates amyloid pathology in Alzheimer's disease model mice. EMBO Mol. Med. 10:e8184. doi: 10.15252/ emmm. 201708184

Kleinberger, G., Yamanishi, Y., Suárez-Calvet, M., Czirr, E., Lohmann, E., Cuyvers, E., et al. (2014). TREM2 mutations implicated in neurodegeneration impair cell surface transport and phagocytosis. Sci. Transl. Med. 6:243ra86. doi: 10.1126/ scitranslmed.3009093

Knowles, T. P. J., Vendruscolo, M., and Dobson, C. M. (2014). The amyloid state and its association with protein misfolding diseases. Nat. Rev. Mol. Cell Biol. 15, 384-396. doi: 10.1038/nrm3810

Koenigsknecht, J., and Landreth, G. (2004). Microglial phagocytosis of fibrillar $\beta$-amyloid through a $\beta 1$ integrin-dependent mechanism. J. Neurosci. 24, 9838 9846. doi: 10.1523/JNEUROSCI.2557-04.2004

Koistinaho, M., Lin, S., Wu, X., Esterman, M., Koger, D., Hanson, J., et al. (2004). Apolipoprotein E promotes astrocyte colocalization and degradation of deposited amyloid- $\beta$ peptides. Nat. Med. 10, 719-726. doi: 10.1038/nm1058

Kollmer, M., Close, W., Funk, L., Rasmussen, J., Bsoul, A., Schierhorn, A., et al. (2019). Cryo-EM structure and polymorphism of $\mathrm{A} \beta$ amyloid fibrils purified from Alzheimer's brain tissue. Nat. Commun. 10:4760.

Krabbe, G., Halle, A., Matyash, V., Rinnenthal, J. L., Eom, G. D., Bernhardt, U., et al. (2013). Functional impairment of microglia coincides with beta-amyloid deposition in mice with Alzheimer-like pathology. PLoS One 8:e60921. doi: 10.1371/journal.pone.0060921

Krasemann, S., Madore, C., Cialic, R., Baufeld, C., Calcagno, N., El Fatimy, R., et al. (2017). The TREM2-APOE pathway drives the transcriptional phenotype of dysfunctional microglia in neurodegenerative diseases. Immunity 47, 566581.e9. doi: 10.1016/j.immuni.2017.08.008

Kumar, D. K. V., Choi, H. S., Washicosky, K. J., Eimer, W. A., Tucker, S., Ghofrani, J., et al. (2016). Amyloid- $\beta$ peptide protects against microbial infection in mouse and worm models of Alzheimer's disease. Sci. Transl. Med. 8:340ra72. doi: 10.1126/scitranslmed.aaf1059

Lambert, J. C., Ibrahim-Verbaas, C. A., Harold, D., Naj, A. C., Sims, R., Bellenguez, C., et al. (2013). Meta-analysis of 74,046 individuals identifies 11 new susceptibility loci for Alzheimer's disease. Nat. Genet. 45, 1452-1458. doi: 10.1038/ng.2802

Lee, C. Y. D., and Landreth, G. E. (2010). The role of microglia in amyloid clearance from the AD brain. J. Neural Transm. 117, 949-960. doi: 10.1007/s00702-0100433-4

Lee, C. Y. D., Tse, W., Smith, J. D., and Landreth, G. E. (2011). Apolipoprotein E promotes-amyloid trafficking and degradation by modulating microglial cholesterol levels. J. Biol. Chem. 287, 2032-2044. doi: 10.1074/jbc.M111. 295451

Leissring, M. A., Farris, W., Chang, A. Y., Walsh, D. M., Wu, X., Sun, X., et al. (2003). Enhanced proteolysis of $\beta$-amyloid in APP transgenic mice prevents plaque formation, secondary pathology, and premature death. Neuron 40, 1087-1093. doi: 10.1016/s0896-6273(03)00787-6

Lessard, C. B., Malnik, S. L., Zhou, Y., Ladd, T. B., Cruz, P. E., Ran, Y., et al. (2018). High-affinity interactions and signal transduction between $\mathrm{A} \beta$ oligomers and TREM 2. EMBO Mol. Med. 10:e9027. doi: 10.15252/emmm.201809027

Liao, M.-C., and Van Nostrand, W. E. (2010). Degradation of Soluble and Fibrillar Amyloid $\beta$-Protein by Matrix Metalloproteinase (MT1-MMP) in Vitro $\dagger$. Biochemistry 49:1127. doi: 10.1021/bi901994d

Lin, Y.-T., Seo, J., Ko, T., Yankner, B. A., and Correspondence, L.-H. T. (2018). APOE4 causes widespread molecular and cellular alterations associated with Alzheimer's disease phenotypes in human iPSC-Derived brain cell types. Neuron 98, 1141. doi: 10.1016/j.neuron.2018.05.008

Liu, Y., Walter, S., Stagi, M., Cherny, D., Letiembre, M., Schulz-Schaeffer, W., et al. (2005). LPS receptor (CD14): a receptor for phagocytosis of Alzheimer's amyloid peptide. Brain 128, 1778-1789. doi: 10.1093/brain/awh531

Lu, A., Magupalli, V. G., Ruan, J., Yin, Q., Atianand, M. K., Vos, M. R., et al. (2014). Unified polymerization mechanism for the assembly of asc-dependent inflammasomes. Cell 156, 1193-1206. doi: 10.1016/j.cell.2014.02.008

Lu, J. X., Qiang, W., Yau, W. M., Schwieters, C. D., Meredith, S. C., and Tycko, R. (2013). XMolecular structure of $\beta$-amyloid fibrils in alzheimer's disease brain tissue. Cell 154:10.1016/j.cell.2013.08.035. doi: 10.1016/j.cell.2013.08.035

Mahley, R. W. (1988). Apolipoprotein E: cholesterol transport protein with expanding role in cell biology. Science 240, 622-630. doi: 10.1126/science. 3283935

Majumdar, A., Capetillo-Zarate, E., Cruz, D., Gouras, G. K., and Maxfield, F. R. (2011). Degradation of Alzheimer's amyloid fibrils by microglia requires delivery of ClC-7 to lysosomes. Mol. Biol. Cell 22, 1664-1676. doi: 10.1091/ mbc.e10-09-0745

Majumdar, A., Chung, H., Dolios, G., Wang, R., Asamoah, N., Lobel, P., et al. (2008). Degradation of fibrillar forms of Alzheimer's amyloid $\beta$-peptide by macrophages. Neurobiol. Aging 29, 707-715. doi: 10.1016/j.neurobiolaging. 2006.12 .001

Mariathasan, S., Weiss, D. S., Newton, K., McBride, J., O’Rourke, K., Roose-Girma, M., et al. (2006). Cryopyrin activates the inflammasome in response to toxins and ATP. Nature 440, 228-232. doi: 10.1038/nature04515

Marschallinger, J., Iram, T., Zardeneta, M., Lee, S. E., Lehallier, B., Haney, M. S. et al. (2020). Lipid-droplet-accumulating microglia represent a dysfunctional and proinflammatory state in the aging brain. Nat. Neurosci. 23, 194-208. doi: 10.1038/s41593-019-0566-1

Martinon, F., Pétrilli, V., Mayor, A., Tardivel, A., and Tschopp, J. (2006). Goutassociated uric acid crystals activate the NALP3 inflammasome. Nature 440, 237-241. doi: 10.1038/nature04516

Masumoto, J., Taniguchi, S., Ayukawa, K., Sarvotham, H., Kishino, T., Niikawa, N., et al. (1999). ASC, a novel 22-kDa protein, aggregates during apoptosis of human promyelocytic leukemia HL-60 cells. J. Biol. Chem. 274, 33835-33838. doi: $10.1074 /$ jbc. 274.48 .33835

Mawuenyega, K. G., Sigurdson, W., Ovod, V., Munsell, L., Kasten, T., Morris, J. C., et al. (2010). Decreased clearance of CNS $\beta$-amyloid in Alzheimer's disease. Science 330:1774. doi: 10.1126/science. 1197623

Meyer, P. F., Tremblay-Mercier, J., Leoutsakos, J., Madjar, C., Lafaille-Maignan, M. É., Savard, M., et al. (2019). A randomized trial of naproxen to slow progress of presymptomatic Alzheimer disease. Neurology 92, E2070-E2080. doi: 10.1212/ WNL.0000000000007232

Meyer-Luehmann, M., Coomaraswamy, J., Bolmont, T., Kaeser, S., Schaefer, C., Kilger, E., et al. (2006). Exogenous induction of cerebral $\beta$-amyloidogenesis is governed bf agent and host. Science 313, 1781-1784. doi: 10.1126/science. 1131864 
Meyer-Luehmann, M., Spires-Jones, T. L., Prada, C., Garcia-Alloza, M., De Calignon, A., Rozkalne, A., et al. (2008). Rapid appearance and local toxicity of amyloid- $\beta$ plaques in a mouse model of Alzheimer's disease. Nature 451, 720-724. doi: 10.1038/nature06616

Michaud, J. P., Hallé, M., Lampron, A., Thériault, P., Préfontaine, P., Filali, M., et al. (2013). Toll-like receptor 4 stimulation with the detoxified ligand monophosphoryl lipid A improves Alzheimer's disease-related pathology. Proc. Natl. Acad. Sci. U.S.A. 110, 1941-1946. doi: 10.1073/pnas. 1215165110

Mittelbronn, M., Dietz, K., Schluesener, H. J., and Meyermann, R. (2001). Local distribution of microglia in the normal adult human central nervous system differs by up to one order of magnitude. Acta Neuropathol. 101, 249-255. doi: $10.1007 / \mathrm{s} 004010000284$

Moore, K. J., El Khoury, J., Medeiros, L. A., Terada, K., Geula, C., Luster, A. D., et al. (2002). A CD36-initiated signaling cascade mediates inflammatory effects of $\beta$-amyloid. J. Biol. Chem. 277, 47373-47379. doi: 10.1074/jbc.M208788200

Morales, R., Moreno-Gonzalez, I., and Soto, C. (2013). Cross-seeding of misfolded proteins: implications for etiology and pathogenesis of protein misfolding diseases. PLoS Pathog. 9:e1003537. doi: 10.1371/journal.ppat.1003537

Moreno-Gonzalez, I., Edwards, G., Salvadores, N., Shahnawaz, M., Diaz-Espinoza, R., and Soto, C. (2017). Molecular interaction between type 2 diabetes and Alzheimer's disease through cross-seeding of protein misfolding. Mol. Psychiatry 22, 1327-1334. doi: 10.1038/mp.2016.230

Mueller-Steiner, S., Zhou, Y., Arai, H., Roberson, E. D., Sun, B., Chen, J., et al. (2006). Antiamyloidogenic and neuroprotective functions of cathepsin b: implications for Alzheimer's disease. Neuron 51, 703-714. doi: 10.1016/j. neuron.2006.07.027

Nagele, R. G., D'Andrea, M. R., Lee, H., Venkataraman, V., and Wang, H. Y. (2003). Astrocytes accumulate $A \beta 42$ and give rise to astrocytic amyloid plaques in Alzheimer disease brains. Brain Res. 971, 197-209. doi: 10.1016/s00068993(03)02361-8

Nielsen, H. M., Mulder, S. D., Beliën, J. A. M., Musters, R. J. P., Eikelenboom, P., and Veerhuis, R. (2010). Astrocytic A $\beta 1-42$ uptake is determined by $A \beta$ aggregation state and the presence of amyloid-associated proteins. Glia 58, 1235-1246. doi: 10.1002/glia.21004

Nilsson, P., Loganathan, K., Sekiguchi, M., Matsuba, Y., Hui, K., Tsubuki, S., et al. (2013). A $\beta$ secretion and plaque formation depend on autophagy. Cell Rep. 5 , 61-69. doi: 10.1016/j.celrep.2013.08.042

Nimmerjahn, A., Kirchhoff, F., and Helmchen, F. (2005). Neuroscience: resting microglial cells are highly dynamic surveillants of brain parenchyma in vivo. Science 308, 1314-1318. doi: 10.1126/science.1110647

Ojala, J., Alafuzoff, I., Herukka, S. K., van Groen, T., Tanila, H., and Pirttilä, T. (2009). Expression of interleukin-18 is increased in the brains of Alzheimer's disease patients. Neurobiol. Aging 30, 198-209. doi: 10.1016/j.neurobiolaging. 2007.06.006

Ono, K., Takahashi, R., Ikeda, T., Mizuguchi, M., Hamaguchi, T., and Yamada, M. (2014). Exogenous amyloidogenic proteins function as seeds in amyloid $\beta$-protein aggregation. Biochim. Biophys. Acta Mol. Basis Dis. 1842, 646-653. doi: 10.1016/j.bbadis.2014.01.002

Paravastu, A. K., Leapman, R. D., Yau, W. M., and Tycko, R. (2008). Molecular structural basis for polymorphism in Alzheimer's $\beta$-amyloid fibrils. Proc. Natl. Acad. Sci. U.S.A. 105, 18349-18354. doi: 10.1073/pnas.0806270105

Paravastu, A. K., Qahwash, I., Leapman, R. D., Meredith, S. C., and Tycko, R. (2009). Seeded growth of $\beta$-amyloid fibrils from Alzheimer's brain-derived fibrils produces a distinct fibril structure. Proc. Natl. Acad. Sci. U.S.A. 106, 7443-7448. doi: 10.1073/pnas.0812033106

Paresce, D. M., Chung, H., and Maxfield, F. R. (1997). Slow degradation of aggregates of the Alzheimer's disease amyloid $\beta$ - protein by microglial cells. J. Biol. Chem. 272, 29390-29397. doi: 10.1074/jbc.272.46.29390

Paresce, D. M., Ghosh, R. N., and Maxfield, F. R. (1996). Microglial cells internalize aggregates of the Alzheimer's disease amyloid $\beta$-protein via a scavenger receptor. Neuron 17, 553-565. doi: 10.1016/s0896-6273(00)80187-7

Parhizkar, S., Arzberger, T., Brendel, M., Kleinberger, G., Deussing, M., Focke, C., et al. (2019). Loss of TREM2 function increases amyloid seeding but reduces plaque-associated ApoE. Nat. Neurosci. 22, 191-204. doi: 10.1038/s41593-0180296-9

Patel, N. S., Paris, D., Mathura, V., Quadros, A. N., Crawford, F. C., and Mullan, M. J. (2005). Inflammatory cytokine levels correlate with amyloid load in transgenic mouse models of Alzheimer's disease. J. Neuroinflammation 2:9.
Perez-Nievas, B. G., and Serrano-Pozo, A. (2018). Deciphering the astrocyte reaction in Alzheimer's disease. Front. Aging Neurosci. 10:114. doi: 10.3389/ fnagi.2018.00114

Petkova, A. T., Leapman, R. D., Guo, Z., Yau, W. M., Mattson, M. P., and Tycko, R. (2005). Self-propagating, molecular-level polymorphism in Alzheimer's $\beta$ amyloid fibrils. Science 307, 262-265. doi: 10.1126/science.1105850

Piccio, L., Buonsanti, C., Mariani, M., Cella, M., Gilfillan, S., Cross, A. H., et al. (2007). Blockade of TREM-2 exacerbates experimental autoimmune encephalomyelitis. Eur. J. Immunol. 37, 1290-1301. doi: 10.1002/eji.200636837

Pihlaja, R., Koistinaho, J., Kauppinen, R., Sandholm, J., Tanila, H., and Koistinaho, M. (2011). Multiple cellular and molecular mechanisms Are involved in human A $\beta$ clearance by transplanted adult astrocytes. Glia 59, 1643-1657. doi: 10.1002/ glia.21212

Pluvinage, J. V., Haney, M. S., Smith, B. A. H., Sun, J., Iram, T., Bonanno, L., et al. (2019). CD22 blockade restores homeostatic microglial phagocytosis in ageing brains. Nature 568, 187-192. doi: 10.1038/s41586-019-1088-4

Poole, S., Singhrao, S. K., Kesavalu, L., Curtis, M. A., and Crean, S. J. (2013). Determining the presence of periodontopathic virulence factors in short-term postmortem Alzheimer's disease brain tissue. J. Alzheimers Dis. 36, 665-677. doi: 10.3233/JAD- 121918

Price, B. R., Sudduth, T. L., Weekman, E. M., Johnson, S., Hawthorne, D., Woolums, A., et al. (2020). Therapeutic Trem2 activation ameliorates amyloidbeta deposition and improves cognition in the 5XFAD model of amyloid deposition. J. Neuroinflammation 17:238.

Qiang, W., Yau, W.-M., Lu, J.-X., Collinge, J., and Tycko, R. (2017). Structural variation in amyloid- $\beta$ fibrils from Alzheimer's disease clinical subtypes. Nature. 541, 217-221. doi: 10.1038/nature20814

Qiu, W. Q., Walsh, D. M., Ye, Z., Vekrellis, K., Zhang, J., Podlisny, M. B., et al. (1998). Insulin-degrading enzyme regulates extracellular levels of amyloid $\beta$ protein by degradation. J. Biol. Chem. 273, 32730-32738. doi: 10.1074/jbc.273. 49.32730

Rasmussen, J., Mahler, J., Beschorner, N., Kaeser, S. A., Häsler, L. M., Baumann, F., et al. (2017). Amyloid polymorphisms constitute distinct clouds of conformational variants in different etiological subtypes of Alzheimer's disease. Proc. Natl. Acad. Sci. U.S.A. 114, 13018-13023. doi: 10.1073/pnas.17132 15114

Readhead, B., Haure-Mirande, J. V., Funk, C. C., Richards, M. A., Shannon, P., Haroutunian, V., et al. (2018). Multiscale analysis of independent Alzheimer's cohorts finds disruption of molecular, genetic, and clinical networks by human herpesvirus. Neuron 99, 64-82. doi: 10.1016/j.neuron.2018.05.023

Reed-Geaghan, E. G., Savage, J. C., Hise, A. G., and Landreth, G. E. (2009). CD14 and toll-like receptors 2 and 4 are required for fibrillar $A \beta$-stimulated microglial activation. J. Neurosci. 29, 11982-11992. doi: 10.1523/JNEUROSCI.3158-09. 2009

Rogers, J., Strohmeyer, R., Kovelowski, C. J., and Li, R. (2002). Microglia and inflammatory mechanisms in the clearance of amyloid $\beta$ peptide. Glia 40 , 260-269. doi: 10.1002/glia.10153

Rubinsztein, D. C., Mariño, G., and Kroemer, G. (2011). Autophagy and aging. Cell, 146, 682-695. doi: 10.1016/j.cell.2011.07.030

Schlepckow, K., Monroe, K. M., Kleinberger, G., Cantuti-Castelvetri, L., Parhizkar, S., Xia, D., et al. (2020). Enhancing protective microglial activities with a dual function TREM 2 antibody to the stalk region. EMBO Mol. Med. 12:e11227. doi: $10.15252 / \mathrm{emmm} .201911227$

Selkoe, D. J. (1998). The cell biology $\beta$-amyloid precursor protein and presenilin in Alzheimer's disease. Trends Cell Biol. 8, 447-453. doi: 10.1016/s0962-8924(98) 01363-4

Serra-Batiste, M., Ninot-Pedrosa, M., Bayoumi, M., Gairí, M., Maglia, G., and Carulla, N. (2016). A $\beta 42$ assembles into specific $\beta$-barrel pore-forming oligomers in membrane-mimicking environments. Proc. Natl. Acad. Sci. U.S.A. 113, 10866-10871. doi: 10.1073/pnas.1605104113

Shankar, G. M., Li, S., Mehta, T. H., Garcia-Munoz, A., Shepardson, N. E., Smith, I., et al. (2008). Amyloid- $\beta$ protein dimers isolated directly from Alzheimer's brains impair synaptic plasticity and memory. Nat. Med. 14, 837-842. doi: $10.1038 / \mathrm{nm} 1782$

Shropshire, T. D., Reifert, J., Rajagopalan, S., Baker, D., Feinstein, S. C., and Daugherty, P. S. (2014). Amyloid $\beta$ peptide cleavage by kallikrein 7 attenuates fibril growth and rescues neurons from $\mathrm{A} \beta$-mediated toxicity in vitro. Biol. Chem. 395, 109-118. doi: 10.1515/hsz-2013-0230 
Simard, A. R., Soulet, D., Gowing, G., Julien, J. P., and Rivest, S. (2006). Bone marrow-derived microglia play a critical role in restricting senile plaque formation in Alzheimer's disease. Neuron 49, 489-502. doi: 10.1016/j.neuron. 2006.01.022

Solé-Domènech, S., Rojas, A. V., Maisuradze, G. G., Scheraga, H. A., Lobel, P., Maxfield, F. R., et al. (2018). Lysosomal enzyme tripeptidyl peptidase 1 destabilizes fibrillar $\mathrm{A} \beta$ by multiple endoproteolytic cleavages within the $\beta$ sheet domain. Proc. Natl. Acad. Sci. U.S.A. 115, 1493-1498. doi: 10.1073/pnas. 1719808115

Song, M., Jin, J. J., Lim, J. E., Kou, J., Pattanayak, A., Rehman, J. A., et al. (2011). TLR4 mutation reduces microglial activation, increases A $\beta$ deposits and exacerbates cognitive deficits in a mouse model of Alzheimer's disease. J. Neuroinflammation 8:92. doi: 10.1186/1742-2094-8-92

Sood, R., Domanov, Y., Pietiäinen, M., Kontinen, V. P., and Kinnunen, P. K. J. (2008). Binding of LL-37 to model biomembranes: insight into target vs host cell recognition. Biochim. Biophys. Acta Biomembr. 1778, 983-996. doi: 10.1016/ j.bbamem.2007.11.016

Soscia, S. J., Kirby, J. E., Washicosky, K. J., Tucker, S. M., Ingelsson, M., Hyman, B., et al. (2010). The Alzheimer's disease-associated amyloid $\beta$-protein is an antimicrobial peptide. PLoS One 5:e9505. doi: 10.1371/journal.pone.000 9505

Spangenberg, E., Severson, P. L., Hohsfield, L. A., Crapser, J., Zhang, J., Burton, E. A., et al. (2019). Sustained microglial depletion with CSF1R inhibitor impairs parenchymal plaque development in an Alzheimer's disease model. Nat. Commun. 10:3758. doi: 10.1038/s41467-019-11674-z

Spitzer, P., Condic, M., Herrmann, M., Oberstein, T. J., Scharin-Mehlmann, M., Gilbert, D. F., et al. (2016). Amyloidogenic amyloid- $\beta$-peptide variants induce microbial agglutination and exert antimicrobial activity. Sci. Rep. 6:32228. doi: $10.1038 /$ srep 32228

Stewart, C. R., Stuart, L. M., Wilkinson, K., Van Gils, J. M., Deng, J., Halle, A., et al. (2010). CD36 ligands promote sterile inflammation through assembly of a Toll-like receptor 4 and 6 heterodimer. Nat. Immunol. 11, 155-161. doi: 10.1038/ni.1836

Swanson, K. V., Deng, M., and Ting, J. P. Y. (2019). The NLRP3 inflammasome: molecular activation and regulation to therapeutics. Nat. Rev. Immunol. 19, 477-489. doi: 10.1038/s41577-019-0165-0

Tahara, K., Kim, H.-D., Jin, J.-J., Maxwell, J. A., Li, L., and Fukuchi, K.-I. (2006). Role of toll-like receptor signalling in Ab uptake and clearance. Brain 129, 3006-3019. doi: 10.1093/brain/awl249

Takahashi, K., Rochford, C. D. P., and Neumann, H. (2005). Clearance of apoptotic neurons without inflammation by microglial triggering receptor expressed on myeloid cells-2. J. Exp. Med. 201, 647-657. doi: 10.1084/jem.20041611

Tamboli, I. Y., Barth, E., Christian, L., Siepmann, M., Kumar, S., Singh, S., et al. (2010). Statins promote the degradation of extracellular amyloid $\beta$-peptide by microglia via stimulation of exosome-associated insulin-degrading enzyme (IDE) secretion. J. Biol. Chem. 285, 37405-37414. doi: 10.1074/jbc.M110. 149468

Tycko, R. (2015). Amyloid polymorphism: structural basis and neurobiological relevance. Neuron. 86, 632-645. doi: 10.1016/j.neuron.2015.03.017

Tzeng, N. S., Chung, C. H., Lin, F. H., Chiang, C. P., Yeh, C.-B., Huang, S. Y., et al. (2018). Anti-herpetic medications and reduced risk of dementia in patients with herpes simplex virus infections-a nationwide, population-based cohort study in Taiwan. Neurotherapeutics 15, 417-429. doi: 10.1007/s13311-0180611-x

Ulrich, J. D., Finn, M. B., Wang, Y., Shen, A., Mahan, T. E., Jiang, H., et al. (2014). Altered microglial response to A $\beta$ plaques in APPPS1-21 mice heterozygous for TREM2. Mol. Neurodegener. 9:20. doi: 10.1186/1750-1326-9-20

Ulrich, J. D., Ulland, T. K., Mahan, T. E., Nyström, S., Peter Nilsson, K., Song, W. M., et al. (2018). ApoE facilitates the microglial response to amyloid plaque pathology. J. Exp. Med. 215, 1047-1058. doi: 10.1084/jem.20171265
Vafadari, B., Salamian, A., and Kaczmarek, L. (2016). MMP-9 in translation: from molecule to brain physiology, pathology, and therapy. J. Neurochem. 139, 91-114. doi: 10.1111/jnc.13415

Venegas, C., Kumar, S., Franklin, B. S., Dierkes, T., Brinkschulte, R., Tejera, D., et al. (2017). Microglia-derived ASC specks crossseed amyloid- $\beta$ in Alzheimer's disease. Nature 552, 355-361. doi: 10.1038/nature25158

Vogt, N. M., Kerby, R. L., Dill-McFarland, K. A., Harding, S. J., Merluzzi, A. P., Johnson, S. C., et al. (2017). Gut microbiome alterations in Alzheimer's disease. Sci. Rep. 7, 13537. doi: 10.1038/s41598-017-13601-y

Wang, R., Sweeney, D., Gandy, S. E., and Sisodia, S. S. (1996). The profile of soluble amyloid $\beta$ protein in cultured cell media. Detection and quantification of amyloid $\beta$ protein and variants by immunoprecipitation-mass spectrometry. J. Biol. Chem. 271, 31894-31902. doi: 10.1074/jbc.271.50.31894

Wang, Y., Ulland, T. K., Ulrich, J. D., Song, W., Tzaferis, J. A., Hole, J. T., et al. (2016). TREM2-mediated early microglial response limits diffusion and toxicity of amyloid plaques. J. Exp. Med. 213, 667-675. doi: 10.1084/jem.20151948

Wilkinson, K., and El Khoury, J. (2012). Microglial scavenger receptors and their roles in the pathogenesis of Alzheimer's disease. Int. J. Alzheimers Dis. 2012:489456. doi: 10.1155/2012/489456

Wozniak, M., Mee, A. P., and Itzhaki, R. F. (2009). Herpes simplex virus type 1 DNA is located within Alzheimer's disease amyloid plaques. J. Pathol. 217, 131-138. doi: 10.1002/path.2449

Wozniak, M. A., Itzhaki, R. F., Shipley, S. J., and Dobson, C. B. (2007). Herpes simplex virus infection causes cellular $\beta$-amyloid accumulation and secretase upregulation. Neurosci. Lett. 429, 95-100. doi: 10.1016/j.neulet.2007.09.077

Wyss-Coray, T., Loike, J. D., Brionne, T. C., Lu, E., Anankov, R., Yan, F., et al. (2003). Adult mouse astrocytes degrade amyloid- $\beta$ in vitro and in situ. Nat. Med. 9, 453-457. doi: 10.1038/nm838

Xiang, X., Werner, G., Bohrmann, B., Liesz, A., Mazaheri, F., Capell, A., et al. (2016). TREM2 deficiency reduces the efficacy of immunotherapeutic amyloid clearance. EMBO Mol. Med. 8, 992-1004. doi: 10.15252/emmm. 201606370

Yan, P., Hu, X., Song, H., Yin, K., Bateman, R. J., Cirrito, J. R., et al. (2006). Matrix Metalloproteinase-9 Degrades Amyloid-Fibrils in Vitro and Compact Plaques in Situ. J. Biol. Chem. 281, 24566-24574. doi: 10.1074/jbc.M602440200

Yin, K. J., Cirrito, J. R., Yan, P., Hu, X., Xiao, Q., Pan, X., et al. (2006). Matrix metalloproteinases expressed by astrocytes mediate extracellular amyloid- $\beta$ peptide catabolism. J. Neurosci. 26, 10939-10948. doi: 10.1523/JNEUROSCI. 2085-06.2006

Yuan, P., Condello, C., Keene, C. D., Wang, Y., Bird, T. D., Paul, S. M., et al. (2016). TREM2 haplodeficiency in mice and humans impairs the microglia barrier function leading to decreased amyloid compaction and severe axonal dystrophy. Neuron 90, 724-739. doi: 10.1016/j.neuron.2016.05.003

Zhang, B., Gaiteri, C., Bodea, L. G., Wang, Z., McElwee, J., Podtelezhnikov, A. A., et al. (2013). Integrated systems approach identifies genetic nodes and networks in late-onset Alzheimer's disease. Cell 153, 707-720. doi: 10.1016/j.cell.2013.03. 030

Zhao, Y., Wu, X., Li, X., Jiang, L. L., Gui, X., Liu, Y., et al. (2018). TREM2 is a receptor for $\beta$-Amyloid that Mediates Microglial Function. Neuron 97, 1023-1031.e7. doi: 10.1016/j.neuron.2018.01.031

Conflict of Interest: The authors declare that the research was conducted in the absence of any commercial or financial relationships that could be construed as a potential conflict of interest.

Copyright (c) 2020 Brown, Radford and Hewitt. This is an open-access article distributed under the terms of the Creative Commons Attribution License (CC BY). The use, distribution or reproduction in other forums is permitted, provided the original author(s) and the copyright owner(s) are credited and that the original publication in this journal is cited, in accordance with accepted academic practice. No use, distribution or reproduction is permitted which does not comply with these terms. 